\title{
Activity of type i methanotrophs dominates under high methane concentration: Methanotrophic activity in slurry surface crusts as influenced by methane, oxygen, and inorganic nitrogen
}

\author{
Duan, Yun Feng; Reinsch, Sabine; Ambus, Per; Elsgaard, Lars; Petersen, Søren O.
}

Published in:

Journal of Environmental Quality

Link to article, DOI:

10.2134/jeq2017.02.0047

Publication date:

2017

Document Version

Peer reviewed version

Link back to DTU Orbit

Citation (APA):

Duan, Y. F., Reinsch, S., Ambus, P., Elsgaard, L., \& Petersen, S. O. (2017). Activity of type i methanotrophs dominates under high methane concentration: Methanotrophic activity in slurry surface crusts as influenced by methane, oxygen, and inorganic nitrogen. Journal of Environmental Quality, 46(4), 767-775. https://doi.org/10.2134/jeq2017.02.0047

\section{General rights}

Copyright and moral rights for the publications made accessible in the public portal are retained by the authors and/or other copyright owners and it is a condition of accessing publications that users recognise and abide by the legal requirements associated with these rights.

- Users may download and print one copy of any publication from the public portal for the purpose of private study or research.

- You may not further distribute the material or use it for any profit-making activity or commercial gain

- You may freely distribute the URL identifying the publication in the public portal 


\title{
Article (refereed) - postprint
}

Duan, Yun-Feng; Reinsch, Sabine; Ambus, Per; Elsgaard, Lars; Petersen, Søren O. 2017. Activity of type I methanotrophs dominates under high methane concentration: methanotrophic activity in slurry surface crusts as influenced by methane, oxygen, and inorganic nitrogen. Journal of Environmental Quality, 46 (4). 767-775. 10.2134/jeq2017.02.0047

\section{(C) 2017}

This version available http://nora.nerc.ac.uk/517125/

NERC has developed NORA to enable users to access research outputs wholly or partially funded by NERC. Copyright and other rights for material on this site are retained by the rights owners. Users should read the terms and conditions of use of this material at http://nora.nerc.ac.uk/policies.html\#access

This document is the author's final manuscript version of the journal article, incorporating any revisions agreed during the peer review process. There may be differences between this and the publisher's version. You are advised to consult the publisher's version if you wish to cite from this article.

The definitive version is available at https://dl.sciencesocieties.org/

\author{
Contact CEH NORA team at \\ noraceh@ceh.ac.uk
}

The NERC and CEH trademarks and logos ('the Trademarks') are registered trademarks of NERC in the UK and other countries, and may not be used without the prior written consent of the Trademark owner. 


\title{
Methanotrophic activity in slurry surface crusts as influenced by $\mathrm{CH}_{4}, \mathrm{O}_{2}$, and inorganic $\mathrm{N}$
}

\author{
Yun-Feng Duan ${ }^{1 *}$, Sabine Reinsch ${ }^{2 \#}$, Per Ambus $^{2 \S}$, Lars Elsgaard $^{1}$, and Søren O. Petersen ${ }^{1}$ \\ ${ }^{1}$ Department of Agroecology, Aarhus University, Blichers Allé 20, DK-8830 Tjele, Denmark \\ ${ }^{2}$ Department of Chemical and Biochemical Engineering, Technical University of Denmark, Frederiksborgvej \\ 399, DK-4000 Roskilde, Denmark
}

* Corresponding Author: Yun-Feng Duan, Department of Agroecology, Aarhus University, Blichers Allé 20, DK-8830 Tjele, Denmark; E-mail: Kevin.YF.Duan@gmail.com.

\# Present address: Centre for Ecology and Hydrology, Deiniol Rd, Bangor Gwynedd, LL57 2 UW, UK

$\S$ Present address: Department of Geosciences and Natural Resource Management, University of Copenhagen, $\varnothing$ ster Voldgade 10, DK-1350 Copenhagen, Denmark

\section{Abbreviations}

MOB: Methane oxidizing bacteria; PLFA: Phospholipid fatty acid; FAME: Fatty acid methyl esters

\section{Keywords}

Methane oxidation; Inorganic nitrogen; Microsensor; PLFA stable-isotope probing; Methane oxidizing bacteria.

\section{Core Ideas}

- Oxygen penetration into surface crusts is shallow.

- Nitrous oxide accumulates at oxic-anoxic interfaces in surface crusts.

- Oxygen availability is important to high-concentration methane oxidation.

- Microbial methane oxidation is affected by interactions of inorganic $\mathrm{N}$ and oxygen.

- Activity of Type I methanotrophs dominates under high methane concentration. 


\section{Abstract}

2 Livestock slurry is a major source of atmospheric $\mathrm{CH}_{4}$, but surface crusts harboring methane oxidizing bacteria (MOB) could mediate against $\mathrm{CH}_{4}$ emissions. This study examined conditions for methane oxidation by in-situ measurements of $\mathrm{O}_{2}$ and $\mathrm{N}_{2} \mathrm{O}$, as a proxy for inorganic $\mathrm{N}$ transformations, in intact crusts using microsensors. This was combined with laboratory incubations of crust material to investigate effects of $\mathrm{O}_{2}$, $\mathrm{CH}_{4}$, and inorganic $\mathrm{N}$ on methane oxidation, using ${ }^{13} \mathrm{CH}_{4}$ to trace $\mathrm{C}$ incorporation into lipids of MOB. Oxygen penetration into the crust was $2-14 \mathrm{~mm}$, confining the potential for aerobic methane oxidation to a shallow

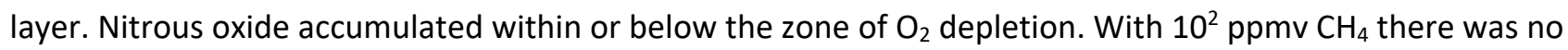
$\mathrm{O}_{2}$ limitation on methane oxidation at $\mathrm{O}_{2}$ concentrations as low as $2 \%$, whereas methane oxidation at $10^{4}$ ppmv $\mathrm{CH}_{4}$ was reduced at $\leq 5 \% \mathrm{O}_{2}$. As hypothesized, methane oxidation was in general inhibited by inorganic $\mathrm{N}$, especially $\mathrm{NO}_{2}{ }^{-}$, and there was an interaction between $\mathrm{N}$ inhibition and $\mathrm{O}_{2}$ limitation at $10^{2} \mathrm{ppmv} \mathrm{CH}_{4}$, as indicated by consistently stronger inhibition of methane oxidation by $\mathrm{NH}_{4}{ }^{+}$and $\mathrm{NO}_{3}{ }^{-}$at $3 \%$ compared to $20 \%$ $\mathrm{O}_{2}$. Recovery of ${ }^{13} \mathrm{C}$ in phospholipid fatty acids suggested that both Type I and Type II MOB were active, with Type I dominating high-concentration methane oxidation. Given the structural heterogeneity of crusts, methane oxidation activity likely varies spatially as constrained by the combined effects of $\mathrm{CH}_{4}, \mathrm{O}_{2}$, and inorganic $\mathrm{N}$ availability in microsites.

\section{Introduction}

18 In regions with intensive livestock production such as Western Europe and North America, up to 40\% of

19 livestock $\mathrm{CH}_{4}$ emissions may be related to manure management (Francesco et al., 2013). In most cases, $\mathrm{CH}_{4}$ 20 capture and/or biofiltration is neither technically feasible nor economical (Melse and van der Werf, 2005),

21 and more cost-effective alternatives must be considered. When manure is stored as liquid slurry, a dense

22 floating crust is often formed either naturally from dry matter in the slurry, or by facilitation of admixing with chopped straw (Hansen et al., 2009). Studies have demonstrated a potential for aerobic methane oxidation in such surface crusts (Petersen and Ambus, 2006; Petersen et al., 2005), where diverse 
suggest that surface crusts could act as a low-cost filter for manure-derived $\mathrm{CH}_{4}$, but the physical, chemical, and biological regulation of methane oxidation inside crusts is largely unknown.

Methane oxidation potential depends on $\mathrm{CH}_{4}$ and $\mathrm{O}_{2}$ availability, which are highly variable due to the heterogeneous structure of the crust. Since surface crusts overlie liquid manure with a high methanogenic potential, they are typically high- $\mathrm{CH}_{4}$ environments with concentrations far above the atmospheric level. We have observed up to $200 \mathrm{ppmv} \mathrm{CH}_{4}$ in the stagnant atmosphere immediately above the surface crust (Y.F. Duan, unpublished data), and headspace $\mathrm{CH}_{4}$ concentrations of $10^{2}$ and $10^{4}$ ppmv were used previously to simulate this range of $\mathrm{CH}_{4}$ availability for $\mathrm{MOB}$ in laboratory incubations (Duan et al., 2013). Due to the often loose structure of the crust, sectioning for extraction and determination of in situ $\mathrm{CH}_{4}$ availability by sampling are impractical. While a $\mathrm{CH}_{4}$ biosensor has been described (Damgaard and Revsbech, 1997), it is not commercially available and has not been tested in heterogeneous environments such as surface crusts. In contrast to $\mathrm{CH}_{4}$, the distribution of $\mathrm{O}_{2}$ in surface crusts can be readily determined using a microsensor (Revsbech, 2005), as demonstrated by Hansen et al. (2009) and Nielsen et al. (2010) who investigated $\mathrm{O}_{2}$ penetration into various slurry crusts.

Inhibition of methane oxidation by inorganic N is known from many environments (Bosse et al., 1993; Dunfield and Knowles, 1995; Wang and Ineson, 2003), as well as in surface crusts (Duan et al., 2013), but stimulation or no effect can also occur (Liu and Greaver, 2009). Livestock slurry and surface crusts are highly enriched in inorganic $\mathrm{N}$ (Table 1): the slurry phase may contain up to $200 \mathrm{mM}$ ammoniacal $\mathrm{N}\left(\mathrm{NH}_{3} / \mathrm{NH}_{4}{ }^{+}\right)$ (Nielsen et al., 2010; Sommer et al., 2007), while up to $35 \mathrm{mM} \mathrm{NO}_{3}^{-}$(Hansen et al., 2009) and $98 \mathrm{mM} \mathrm{NO}_{2}^{-}$ (Nielsen et al., 2010) have been found at the oxic-anoxic interface in surface crusts. These concentration ranges (Table 1) represent a high variability of inorganic $\mathrm{N}$ at microsites within surface crusts due to fluctuations in water content as a result of precipitation and insolation (Nielsen et al., 2010). Due to this heterogeneity, bulk $\mathrm{N}$ concentrations are insufficient to characterize $\mathrm{N}$ distribution and thus potential interference with methane oxidation in microsites. While specialized sensors are available to determine micro-scale concentrations of $\mathrm{NH}_{4}{ }^{+}, \mathrm{NO}_{2}{ }^{-}$, and $\mathrm{NO}_{3}{ }^{-}$in aqueous environments (De Beer et al., 1997; De Beer 
et al., 1991; Larsen et al., 1996), they are difficult to apply in unsaturated matrices such as surface crusts, where contact to liquid phase may be intermittent. Instead, the accumulation of $\mathrm{N}_{2} \mathrm{O}$ in the crust was used in this study as a proxy for the distribution of $\mathrm{N}$ transformations and thus presence of inorganic $\mathrm{N}$ (Larsen et al., 1996), as both nitrification and denitrification can produce $\mathrm{N}_{2} \mathrm{O}$ under sub-oxic conditions (Bollmann and Conrad, 1998).

The effects of environmental factors on methane oxidation in surface crusts will ultimately depend on the MOB present (Bodelier, 2011; Hu and Lu, 2015). Aerobic MOB have been conventionally categorized into Type I and Type II based on phylogenetic and functional traits, including the presence of signature 16-carbon $\left(C_{16}\right)$ or 18-carbon ( $\left.C_{18}\right)$ phospholipid fatty acids (PLFAs) (Hanson and Hanson, 1996). Type I MOB have been reported to thrive in $\mathrm{N}$-sufficient, high- $\mathrm{O}_{2}$ and low- $\mathrm{CH}_{4}$ environments, whereas Type II MOB seem to favor the opposite (Amaral et al., 1995; Amaral and Knowles, 1995; Graham et al., 1993). It is still unclear to what extent $\mathrm{CH}_{4}, \mathrm{O}_{2}$, and inorganic $\mathrm{N}$ conditions will select one type of $\mathrm{MOB}$ over another in surface crusts, but previous studies found that Type I MOB are more abundant and diverse than Type II MOB in this environment (Duan et al., 2014; Hansen et al., 2009; Nielsen et al., 2013). In recent years, novel methane oxidation pathways, such as $\mathrm{NO}_{2}^{-}$dependent anaerobic methane oxidation (Ettwig et al., 2010; Welte et al., 2016), as well as aerobic methane oxidation coupled with partial denitrification (Kits et al., 2015a; Kits et al., 2015b), have also been described, but the importance of these processes and the presence of relevant microorganisms in surface crusts remain unclear.

A main objective of this study was to examine the potential for microbial methane oxidation under realistic storage conditions by characterizing in situ distributions of $\mathrm{O}_{2}$ and inorganic $\mathrm{N}$ transformations in a cattle slurry surface crust using microsensors. Effects and interactions of $\mathrm{O}_{2}$ and inorganic $\mathrm{N}$ species with respect to methane oxidation could not be quantified in situ where microbial activities occur in micro-sites, and instead this was investigated under controlled laboratory conditions. Here, ${ }^{13} \mathrm{CH}_{4}$ was used as substrate, allowing ${ }^{13} \mathrm{C}$ stable isotope probing of PLFAs to study the involvement of Type I and Type II MOB in methane oxidation in surface crusts. Based on previous results (Duan et al., 2014; Duan et al., 2013) we hypothesized that 
methane oxidation activity in surface crusts would be determined by both $\mathrm{CH}_{4}$ and $\mathrm{O}_{2}$ availability, and inhibited by inorganic $\mathrm{N}$, and that Type I MOB would be primarily responsible for methane oxidation.

\section{$78 \quad$ Materials and Methods}

\section{Microsensor Measurement of $\mathrm{O}_{2}$ and $\mathrm{N}_{2} \mathrm{O}$ Distribution}

80 Dairy cattle slurry was collected from a full-scale manure storage facility in May, 2012, and transferred to two tanks at a pilot-scale storage system (Petersen et al., 2009) at Aarhus University (Foulum, Denmark). The slurry was stored for six weeks prior to the measurement in June, by which time a 5-6 cm thick surface crust with a stable structure had developed on top of the slurry. The development of surface crust reflected typical storage conditions, where a new crust is formed following the mixing of slurry in spring for field application.

Oxygen and $\mathrm{N}_{2} \mathrm{O}$ concentration profiles in the surface crust were determined using, respectively, an $\mathrm{O}_{2}$ and a $\mathrm{N}_{2} \mathrm{O}$ microsensor with a tip diameter of $0.5 \mathrm{~mm}$ (both produced by Unisense, Aarhus, Denmark). Both microsensors were calibrated according to manufacturer's instructions. Detection limits for $\mathrm{O}_{2}$ and $\mathrm{N}_{2} \mathrm{O}$ were $0.3 \mu \mathrm{mol} \mathrm{L} \mathrm{L}^{-1}$ and $0.1 \mu \mathrm{mol} \mathrm{L} \mathrm{L}^{-1}$, respectively.

A custom-made mounting system was used to place the microsensors over the surface crust (Supplemental

Fig. S1). Oxygen profiles were recorded at $20-\mathrm{cm}$ intervals from 20 to $180 \mathrm{~cm}$ along the $200-\mathrm{cm}$ diameter of the storage tank. During measurement, the microsensor was introduced stepwise into the crust at $0.5 \mathrm{~mm}$ increments to a maximum depth of $30 \mathrm{~mm}$ using a motorized micromanipulator (Unisense). At each depth, the microsensor was stationary for $3 \mathrm{~s}$ to allow gas equilibration, and then the $\mathrm{O}_{2}$ concentration was determined as the average of a $3 \mathrm{~s}$ reading. The signal was amplified by a multimeter (Unisense), and registered by the SensorTrace PRO v3.0 software (Unisense). Nitrous oxide profiles were determined at the same locations as $\mathrm{O}_{2}$ profiles, but with a $+2 \mathrm{~mm}$ offset to avoid any disturbance to the crust caused by the $\mathrm{O}_{2}$ microsensor. The $\mathrm{N}_{2} \mathrm{O}$ profiles were recorded with the same procedure as $\mathrm{O}_{2}$ profiles, and initially over the 
same depth. However, due to incidences of significant $\mathrm{N}_{2} \mathrm{O}$ accumulation at $30 \mathrm{~mm}$ depth, the maximum depth was extended to $60 \mathrm{~mm}$ starting from the 5 th profile (at $100 \mathrm{~cm}$ distance from the edge).

Due to the uneven surface of the crust, a fixed depth cannot accurately define the crust-air interface. For $\mathrm{O}_{2}$, an abrupt decrease from atmospheric concentration defined the crust-air interface. For $\mathrm{N}_{2} \mathrm{O}$, which was produced inside the crust and diffused towards the atmosphere, the crust-air interface was defined as the depth where $\mathrm{N}_{2} \mathrm{O}$ concentration dropped below the detection limit. Using these two criteria, the $\mathrm{O}_{2}$ and $\mathrm{N}_{2} \mathrm{O}$ concentration profiles were aligned.

\section{Methane Oxidation in Response to $\mathrm{O}_{2}$ and $\mathrm{N}$ Amendments}

107 Surface crust was collected from a full-scale storage tank at the biogas plant of Aarhus University in March, 108 2012. The 10-cm surface crust had developed on slurry co-digested with maize silage. Homogenized crust samples were stored in closed plastic containers at $2^{\circ} \mathrm{C}$ until used for experiments within four weeks. Duan et al. (2013) showed that MOB can survive and recover activity under these storage conditions for at least

111 three months.

112 Methane oxidation rates were determined by incubating 3-g crust samples in liquid media under a controlled

113 atmosphere. To reduce background $\mathrm{N}$, crusts were washed three times by vortexing with $20 \mathrm{~mL}$ deionized 114 water followed by centrifugation at $10,000 \times g$ for $10 \mathrm{~min}$. The washing did not remove all $\mathrm{NH}_{4}{ }^{+}$, but the 115 residual $\mathrm{NH}_{4}{ }^{+}$was negligible compared to the received $\mathrm{NH}_{4}{ }^{+}$amendment (Duan et al., 2013). Washed crust 116 materials were transferred to $125 \mathrm{~mL}$ serum bottles, and resuspended in $20 \mathrm{~mL}$ basal salt (BS) medium 117 prepared according to Whittenbury et al. (1970), but excluding $N$ salts. The BS medium was dispensed using 118 a customized system designed to remove dissolved $\mathrm{O}_{2}$ and maintain anoxia during sample preparation 119 (Supplemental Fig. S2).

120 Various treatments with combinations of different $\mathrm{CH}_{4}, \mathrm{O}_{2}$, and inorganic $\mathrm{N}$ were prepared (Table 2). For $\mathrm{N}$ 121 amendments, pre-made solutions of $\left(\mathrm{NH}_{4}\right)_{2} \mathrm{SO}_{4}, \mathrm{KNO}_{3}$, or $\mathrm{KNO}_{2}$ were injected into the serum bottles to 
122 achieve the desired $\mathrm{N}$ concentrations. The bottles were purged using a vacuum pump and refilled with helium, and this step was repeated three times to exhaust residual $\mathrm{O}_{2}$. Then, air and ${ }^{13} \mathrm{C}$-labeled $\mathrm{CH}_{4}(99$ atom $\%{ }^{13} \mathrm{C}$, ISOTEC, Miamisburg, $\mathrm{OH}, \mathrm{USA}$ ) were injected to achieve the desired headspace gas concentrations. To meet the requirement for $\mathrm{CO}_{2}$ by some $\mathrm{MOB}, 4 \mathrm{~mL}$ pure $\mathrm{CO}_{2}$ was also added (Acha et al., 2002). After gas injection, the bottles were mounted on a rotary shaker at $150 \mathrm{rpm}$ for $30 \mathrm{~min}$ to allow for liquid-gas equilibration. Headspace $\mathrm{O}_{2}$ concentrations were verified using an Agilent 3000A MicroGC (Hørsholm, Denmark) as described by (Petersen et al., 2009). For treatments with $0 \% \mathrm{O}_{2}$, residual headspace $\mathrm{O}_{2}$ concentration was undetectable $(<10-20 \mathrm{ppmv})$. The bottles were then incubated on a rotary shaker at $200 \mathrm{rpm}$ at ca. $21^{\circ} \mathrm{C}$; Duan et al. (2013) had shown that there is no gas diffusion limitation under these incubation conditions. Headspace $\mathrm{CH}_{4}$ concentrations were measured after $0,2,4,6,8,24,48$, and $72 \mathrm{~h}$ using a Shimadzu 14B GC as described by Duan et al. (2013).

In each batch of assays, a control with crust material in $\mathrm{N}$-free BS medium at atmospheric $\mathrm{O}_{2}$ concentration was included to check for batch-to-batch variations in crust MOB activity, and a blank control without crust material to correct for loss of pressure during repeated gas samplings.

First-order rate constants for the first $8 \mathrm{~h}$ of incubation and relative activities were calculated according to Duan et al. (2013). First-order rate constants were compared between treatments using R v3.2.2 (R Core Team, 2015). For each $\mathrm{CH}_{4}$ concentration, effects of $\mathrm{O}_{2}$ and inorganic $\mathrm{N}$, and their interaction, were analyzed by a two-way ANOVA. Differences between treatments were determined by Duncan's post-hoc multiple comparison test.

\section{PLFA Extraction and GC-c-IRMS Analysis}

142 After incubation with ${ }^{13} \mathrm{C}$-labeled $\mathrm{CH}_{4}$, selected crust samples were processed for PLFA analysis (Table 2).

143 Prior to lipid extraction it was necessary to reduce the organic load since otherwise the humic material 144 would bind the chloroform phase and prevent isolation of lipid-soluble compounds. Crust samples were 145 vortexed and centrifuged for $10 \mathrm{~min}$ at $3000 \times g$ to extract microbial cells. The supernatant was filtered 

through $0.2 \mu \mathrm{m}$ chloroform-soluble polycarbonate filters, and the material retained on the filter was used for lipid extraction. Hence, lipid results refer to the fraction of extractable low particle size material only. Polar lipid fatty acid methyl esters (FAMEs) from each filter were prepared as previously described by

149 Petersen et al. (2002).

FAMEs were analyzed using a HP6890 GC (Agilent, Santa Clara, CA, USA) coupled via a GC combustion interface (Thermo Scientific, Bremen, Germany) in continuous flow mode to a Finnigan Delta ${ }^{\text {PLus }}$ isotope ratio mass spectrometer (Thermo Scientific, Bremen, Germany). The oxidation reactor on the interface was maintained at $940{ }^{\circ} \mathrm{C}$, the reduction reactor at $650{ }^{\circ} \mathrm{C}$. Samples $(1 \mu \mathrm{L})$ were injected at $240{ }^{\circ} \mathrm{C}$ in splitless mode. The column temperature was held at $50{ }^{\circ} \mathrm{C}$ for $2 \mathrm{~min}$, then increased at $15^{\circ} \mathrm{C} \mathrm{min}^{-1}$ to $100{ }^{\circ} \mathrm{C}$, subsequently at $2{ }^{\circ} \mathrm{C} \mathrm{min}-1$ to $220^{\circ} \mathrm{C}$, and finally at $15^{\circ} \mathrm{C} \mathrm{min}^{-1}$ to $240{ }^{\circ} \mathrm{C}$, where the final temperature was held for $5 \mathrm{~min}$. Separated compounds were measured against a $\mathrm{CO}_{2}$ reference gas calibrated with reference to Vienna PeeDee belemnite. PLFAs were identified by relative retention time comparing samples against a FAME standard mix (Supelco 37 component FAME mix, 47885-U, Sigma Aldrich). All $\delta^{13} \mathrm{C}$ values were corrected for the methanol $\mathrm{C}$ added during methanolysis:

$$
\delta^{13} \mathrm{C}_{\mathrm{FAME}}=\frac{\left(\mathrm{N}_{\mathrm{FA}}+1\right) \delta^{13} \mathrm{C}_{\mathrm{FAME}}-\delta^{13} \mathrm{C}_{\mathrm{MeOH}}}{\mathrm{N}_{\mathrm{FA}}}
$$

where $\mathrm{N}_{\mathrm{FA}}$ refers to the number of carbon atoms of the fatty acid component, $\delta^{13} \mathrm{C}_{\mathrm{FAME}}$ is the observed $\delta^{13} \mathrm{C}$ value of the FAME, and $\delta^{13} \mathrm{C}_{\mathrm{MeOH}}$ is the $\delta^{13} \mathrm{C}$ value of the methanol used for methanolysis $(-37.7 \%$ \% $\pm 3.2 \%$ ).

163 The $\delta^{13} \mathrm{C}$ isotope ratios were converted to atom\%, and atom\% excess was then calculated by subtraction of 164 an unlabeled control. The incorporation of ${ }^{13} \mathrm{CH}_{4}$ into membrane PLFAs $\left(n_{13 \mathrm{C}}, \mathrm{nmol}\right)$ was calculated as $n_{13 \mathrm{C}}=$

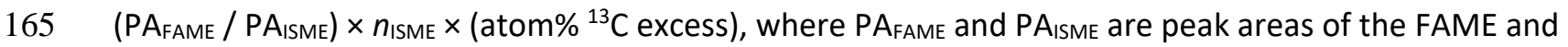
internal standard Me19:0, respectively, and $n_{\text {ISME }}(\mathrm{nmol} C)$ is the concentration of the internal standard fatty acid. The lower limit of identified peaks corresponded to $0.1 \mathrm{ng}{ }^{13} \mathrm{C} \mathrm{g}^{-1}$ crust material. 
In view of the uncertain recovery of microbial cells following centrifugation and filtration, statistical testing of treatment effects was not performed, and results will only be presented as means \pm standard errors.

\section{Results}

\section{Oxygen and $\mathrm{N}_{2} \mathrm{O}$ Distribution in Natural Surface Crusts}

172 Surface crusts from the two storage tanks showed a high spatial variability in shape and penetration depth of 173 individual $\mathrm{O}_{2}$ and $\mathrm{N}_{2} \mathrm{O}$ profiles, yet the distribution patterns were qualitatively similar between the two 174 tanks. Thus, results presented here are from one of the storage tanks only (Fig. 1).

Oxygen penetration depth varied from 2 to $14 \mathrm{~mm}$, with either a steep or more gradual decline in concentration. Irregularities such as a secondary increase following the initial decline were also observed

177 (e.g., at $60 \mathrm{~cm}$ ).

Nitrous oxide profiles showed peak concentrations at 5-25 mm depth below the crust-air interface. Some $\mathrm{N}_{2} \mathrm{O}$ profiles consisted of more than one zone of $\mathrm{N}_{2} \mathrm{O}$ accumulation (e.g., at 60,100 , and $160 \mathrm{~cm}$ ). Maximum $\mathrm{N}_{2} \mathrm{O}$ accumulation often coincided with sub-oxic or anoxic zones indicated by $\mathrm{O}_{2}$ profiles. In a few cases (e.g., at 60 and $180 \mathrm{~cm}$ ), $\mathrm{N}_{2} \mathrm{O}$ production took place where $\mathrm{O}_{2}$ availability was relatively high.

\section{Response of $\mathrm{CH}_{4}$ Oxidation to $\mathrm{O}_{2}$ Concentrations}

183 Figure 2 shows the changes in headspace $\mathrm{CH}_{4}$ concentrations during the 72 - $\mathrm{h}$ incubation study with different initial $\mathrm{O}_{2}$ levels and two initial $\mathrm{CH}_{4}$ levels. For both $10^{2}$ and $10^{4} \mathrm{ppmv} \mathrm{CH}_{4}$, consistent methane consumption throughout the incubation was observed only at $20 \%$ initial $\mathrm{O}_{2}$, with a $>90 \%$ decline in headspace $\mathrm{CH}_{4}$ concentrations after $72 \mathrm{~h}$. In treatments with $\leq 5 \%$ initial $\mathrm{O}_{2}, \mathrm{CH}_{4}$ consumption was generally observed within the first $24 \mathrm{~h}$, followed by net $\mathrm{CH}_{4}$ accumulation. At $0 \%$ initial $\mathrm{O}_{2}$, net $\mathrm{CH}_{4}$ production was observed throughout the incubation. 
189 The strength of methane oxidation activity was expressed as first-order rate constants during the first $8 \mathrm{~h}$ of 190 incubation (Fig. 3). At $10^{2} \mathrm{ppmv}$ initial $\mathrm{CH}_{4}$ there were no significant differences in first-order rate constants 191 at $\mathrm{O}_{2}$ levels from $20 \%$ down to $2 \%$, but at $1 \% \mathrm{O}_{2}$ the rate was significantly impaired. At $10^{4} \mathrm{ppmv}$ initial $\mathrm{CH}_{4}$, 192 methane oxidation rates were significantly reduced at lower $\mathrm{O}_{2}$ levels, though not significantly different 193 between $2 \%$ and $1 \% \mathrm{O}_{2}$.

194 Response of $\mathrm{CH}_{4}$ Oxidation to Interactions between $\mathrm{O}_{2}$ and Inorganic $\mathrm{N}$

195 When samples with manipulated $\mathrm{O}_{2}$ and $\mathrm{CH}_{4}$ concentrations were amended with inorganic $\mathrm{N}$, complex 196 patterns in microbial methane oxidation were observed. For each of the two initial $\mathrm{CH}_{4}$ concentrations, two197 way ANOVA showed significant effects of $\mathrm{O}_{2}$ concentrations and $\mathrm{N}$ amendments, as well as their interaction, 198 on methane oxidation rates.

199 At $10^{2} \mathrm{ppmv} \mathrm{CH}_{4}$, first-order rate constants in all $\mathrm{N}$-amended samples were lower than in the $\mathrm{N}$-free control 200 (Table 3). The inhibition was strengthened at increasing concentrations of both $\mathrm{NH}_{4}{ }^{+}$and $\mathrm{NO}_{3}{ }^{-}$. Samples treated with $\mathrm{NO}_{3}{ }^{-}$consistently showed less inhibition than treatments receiving other $\mathrm{N}$ salts, whereas $\mathrm{NO}_{2}{ }^{-}$ was a potent inhibitor as indicated by similar inhibitions with $1 \mathrm{mM} \mathrm{NO}_{2}^{-}$and $50 \mathrm{mM} \mathrm{NH}_{4}{ }^{+}$. At $3 \% \mathrm{O}_{2}$, inhibition by individual $\mathrm{N}$ species and concentrations was slightly stronger than at $20 \% \mathrm{O}_{2}$, but the difference 204 was not always statistically significant.

205 At $10^{4} \mathrm{ppmv} \mathrm{CH}_{4}$ the order of inhibition by different $\mathrm{N}$ species was similar to that at $10^{2} \mathrm{ppmv} \mathrm{CH}_{4}$, with $\mathrm{NO}_{2}^{-}$ as the strongest inhibitor (Table 3). Yet, several $\mathrm{NO}_{3}{ }^{-}$treatments caused a weak stimulation rather than inhibition as compared to the $\mathrm{N}$-free control. Generally, the $\mathrm{N}$ amendments inhibited methane oxidation at $20 \% \mathrm{O}_{2}$, but not at $3 \% \mathrm{O}_{2}$, where low rates were already observed in the $\mathrm{N}$-free control. One exception, 209 though, was the inhibition caused by the treatment with $50 \mathrm{mM} \mathrm{NH}_{4}^{+}$. 


\section{${ }^{13}$ C Incorporation into $C_{16}$ and $C_{18}$ PLFAs}

211 The yields of PLFA varied considerably between samples, and ${ }^{13} \mathrm{C}$ incorporation was below the detection limit

212 for several PLFAs, precluding a detailed quantitative analysis. Instead of absolute PLFA concentrations, an

213 index based on peak area was calculated (Fig. 4, a1-a4). Recovery of ${ }^{13} \mathrm{C} \mathrm{PLFAs} \mathrm{was} \mathrm{consistently} \mathrm{low} \mathrm{in}$

214 incubations with $10^{2}$ ppmv $\mathrm{CH}_{4}$ (Fig. 4, a1). At $10^{4}$ ppmv $\mathrm{CH}_{4}$ there was an 8-9 times higher ${ }^{13} \mathrm{C}$ recovery in

215 PLFAs at $20 \%$ and $3 \% \mathrm{O}_{2}$ than at $1 \% \mathrm{O}_{2}$ (Fig. 4, a2). While $\mathrm{NH}_{4}{ }^{+}$and $\mathrm{NO}_{3}{ }^{-}$considerably reduced ${ }^{13} \mathrm{C}$ recovery,

$216 \mathrm{NO}_{2}{ }^{-}$caused no or only moderate inhibition of ${ }^{13} \mathrm{C}$ recovery (Fig. 4, a3 and a4). The total recovery of ${ }^{13} \mathrm{C}$ was

217 5-15 times higher with $\mathrm{NO}_{2}^{-}$amendment than with the other two $\mathrm{N}$ species.

218 Two ${ }^{13} \mathrm{C}$-labeled PLFA clusters, $\mathrm{C}_{16}$ and $\mathrm{C}_{18}$, were defined in accordance with the predominance of these 219 PLFAs in Type I and Type II MOB, respectively (Bodelier et al., 2009). The $C_{16}$ cluster included peaks identified 220 as $16: 0,16: 1 \omega 6,16: 1 \omega 7$, and $16: 1 \omega 8$, whereas the $C_{18}$ cluster included $18: 0,18: 1 \omega 7,18: 1 \omega 9$, and probably 221 also small peaks of $18: 1 \omega 8$. Also, $16: 1 \omega 6$ probably co-eluted with $10 M e 16: 0$, and $16: 1 \omega 8$ with i17:0, but this 222 did not influence the calculated ${ }^{13} \mathrm{C}$ incorporation for the cluster.

223 Due to the low recovery of total ${ }^{13} \mathrm{C}$ PLFA (Fig. 4, a1) and low percentage (3-9\%) of ${ }^{13} \mathrm{C}^{\text {in }} \mathrm{C}_{16}$ and $\mathrm{C}_{18}$ clusters

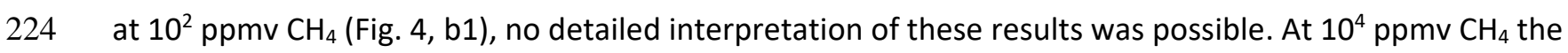
225 recovery of ${ }^{13} \mathrm{C}$ in the $\mathrm{C}_{16}$ and $\mathrm{C}_{18}$ clusters together accounted for an average of $52 \%$ of ${ }^{13} \mathrm{C}$ recovered in PLFAs. A higher percentage of ${ }^{13} \mathrm{C}$ was always recovered in the $C_{16}$ than in the $C_{18}$ cluster, and the percentage of the $\mathrm{C}_{16}$ cluster was particularly high in treatments with $\mathrm{NO}_{2}{ }^{-}$amendment (Fig. 4 , b3 and b4).

\section{Discussion}

229 Due to the heterogenous nature of surface crusts, microbial activities within this environment are controlled 230 by physical and chemical properties of individual microsites rather than overall bulk properties. However, detailed analysis of surface crusts is challenged by the often loose and fibrous structure of the material, and this was also the case with the straw-containing cattle slurry crust used in this study. Therefore, we chose to 
characterize $\mathrm{O}_{2}$ and inorganic $\mathrm{N}$ distributions in situ by microsensors, while regulation of microbial activities were investigated by controlled laboratory incubations. For logistic reasons, the in situ gas measurements and laboratory incubations were performed using different surface crusts. However, previous studies have shown that crusts of different origin are qualitatively similar with respect to, e.g., depth of $\mathrm{O}_{2}$ penetration and the presence of MOB (Duan et al., 2014; Hansen et al., 2009; Nielsen et al., 2010; Nielsen et al., 2013), and results from the two parts are therefore analyzed and discussed together.

\section{Effects of $\mathrm{O}_{2}$ Limitation and $\mathrm{N}$ Amendments}

240 Methane oxidation kinetics are complex as the reaction involves two substrates, $\mathrm{CH}_{4}$ and $\mathrm{O}_{2}$ (Cai and Yan, 1999). We were not able to monitor $\mathrm{O}_{2}$ concentrations during incubation, but instead calculated $\mathrm{O}_{2}$ consumption by $\mathrm{MOB}$ based on the amounts of $\mathrm{CH}_{4}$ consumed, the stoichiometry of methane oxidation

243 (Urmann et al., 2007), and the diffusion coefficients of $\mathrm{CH}_{4}$ and $\mathrm{O}_{2}$ in water (Broecker and Peng, 1974)

244 (Supplemental Table S1). These calculations suggested that there was no diffusional limitation of $\mathrm{O}_{2}$ for methane oxidation, and that the amounts of $\mathrm{O}_{2}$ used for methane oxidation were $<10 \%$ of the available $\mathrm{O}_{2}$ even at $1 \%$ initial $\mathrm{O}_{2}$. Thus, depletion of $\mathrm{O}_{2}$ during incubation must have been mainly due to aerobic processes other than methane oxidation, i.e., any $\mathrm{O}_{2}$ limitation for $\mathrm{MOB}$ activity reflected competition for $\mathrm{O}_{2}$ against other aerobes. Headspace $\mathrm{CH}_{4}$ concentrations decreased exponentially during the first $8 \mathrm{~h}$, indicating that the rates of $\mathrm{CH}_{4}$ uptake depended mainly on $\mathrm{CH}_{4}$ availability. Therefore, the reaction was approximated by first-order reaction kinetics, which have also been used previously in studies of microbial methane oxidation (De Visscher et al., 1999; King and Schnell, 1994; King and Schnell, 1998; Petersen and Ambus, 2006). The apparent first-order kinetics suggest that the rate of $\mathrm{CH}_{4}$ uptake, and thus demand for $\mathrm{O}_{2}$, was proportional to the $\mathrm{CH}_{4}$ concentration, which explains our observation that methane oxidation became more affected by $\mathrm{O}_{2}$ limitation at $10^{4} \mathrm{ppmv}$ than at $10^{2}$ ppmv $\mathrm{CH}_{4}$ (Fig. 3). of free ammonia $\left(\mathrm{NH}_{3}\right)$, which is a competitive inhibitor for methane oxidation (Carlsen et al., 1991; Gulledge 
and Schimel, 1998). In both the present (Table 3) and a previous study (Duan et al., 2013), inhibition by ammonia was less at $10^{4}$ compared to $10^{2} \mathrm{ppmv} \mathrm{CH}_{4}$, suggesting that competitive inhibition is important for effects of ammonia. The observations that $\mathrm{NO}_{2}^{-}$was a more potent inhibitor of methane oxidation than $\mathrm{NO}_{3}{ }^{-}$ was also consistent with the report by Duan et al. (2013), where the concentration of $\mathrm{NO}_{3}{ }^{-}$resulting in $50 \%$ inhibition was 100 -fold higher than that of $\mathrm{NO}_{2}^{-}$. It is likely that these $\mathrm{N}$ species both inhibit methane oxidation via nitrite toxicity (Stein and Klotz, 2011).

We further tested interactions of $\mathrm{N}$ inhibition with $\mathrm{O}_{2}$ availability by comparing relative activities. If there were an interaction between $\mathrm{O}_{2}$ and inorganic $\mathrm{N}$, a given $\mathrm{N}$ amendment would result in different degree of inhibition at $20 \%$ and $3 \% \mathrm{O}_{2}$ concentrations. At $10^{2}$ ppmv initial $\mathrm{CH}_{4}, 10 \mathrm{mM}$, but not $50 \mathrm{mM}, \mathrm{NH}_{4}{ }^{+}$or $\mathrm{NO}_{3}{ }^{-}$ amendments caused a stronger inhibition at $3 \%$ than at $20 \% \mathrm{O}_{2}$ (Table 3), confirming an interaction between $\mathrm{N}$ inhibition and $\mathrm{O}_{2}$ limitation at low $\mathrm{N}$ concentrations. At $10^{4} \mathrm{ppmv} \mathrm{CH}_{4}$, the fact that $\mathrm{N}$ amendments generally inhibited methane oxidation at $20 \% \mathrm{O}_{2}$ but not further at $3 \% \mathrm{O}_{2}$ suggested that high-concentration methane oxidation is more sensitive to $\mathrm{O}_{2}$ limitation rather than to $\mathrm{N}$ inhibition.

270 Generally, as an essential substrate for aerobic methane oxidation, $\mathrm{O}_{2}$ has a direct and immediate effect on aerobic methanotrophic activity. On the other hand, the mechanism of $\mathrm{N}$ inhibition on methane oxidation is much more complex and may include immediate toxicity to cell growth and enzyme synthesis, as well as delayed influence on microbial community composition (Bodelier and Laanbroek, 2004). The mechanisms behind interactions between controlling factors in surface crusts could not be explained with the data presented here, and more research is needed to further elucidate this matter.

\section{${ }^{13}$ C PLFA Signatures for MOB}

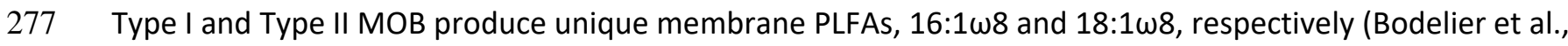
278 2009; Hanson and Hanson, 1996). These signature PLFAs are not always present, or present only in low 279 amounts. However, there is also a general predominance of $\mathrm{C}_{16}$ and $\mathrm{C}_{18}$ PLFAs among Type I and Type II 280 MOB, respectively (Bodelier et al., 2009), and this has been used to evaluate sources of methane oxidation 
by stable isotope probing (Qiu et al., 2008). In the present study, both types of MOB were active, with Type I MOB dominating the methanotrophic activity especially where $\mathrm{CH}_{4}$ availability was high (Fig. 4, b1 and b2). Molecular analyses of microflora in other crust materials likewise suggested that Type I MOB dominated the methanotrophic community in terms of both diversity and abundance (Duan et al., 2014).

Interestingly, the incorporation of ${ }^{13} \mathrm{C}$ into PLFAs was high in surface crusts incubated with $\mathrm{NO}_{2}{ }^{-}$as compared to those with other $\mathrm{N}$ species (Fig. 4, a3 and a4), especially considering that crusts incubated with $\mathrm{NO}_{3}{ }^{-}$had over two-fold higher ${ }^{13} \mathrm{CH}_{4}$ uptake than $\mathrm{NO}_{2}^{-}$treatments (data not shown). Roslev et al. (1997) reported that $\mathrm{NH}_{4}{ }^{+}$decreased $\mathrm{C}$ conversion efficiency and increased respiration of $\mathrm{C}$ assimilated by $\mathrm{MOB}$, which is consistent with the low ${ }^{13} \mathrm{C}$ recovery from $\mathrm{NH}_{4}{ }^{+}$treatments in this study. However, the mechanism by which $\mathrm{NO}_{3}{ }^{-}$and $\mathrm{NO}_{2}{ }^{-}$could interfere with $\mathrm{C}$ assimilation for $\mathrm{MOB}$ remains unclear. Alternative pathways for $\mathrm{CH}_{4}$ uptake may have contributed to the particularly high ${ }^{13} \mathrm{C}$ assimilation in $\mathrm{NO}_{2}{ }^{-}$amended crusts. The microorganism Candidatus Methylomirabilis oxyfera is able to couple anaerobic methane oxidation with nitrite reduction (Ettwig et al., 2010), and may be widespread in natural environments (Ettwig et al., 2009; Wang et al., 2012; Zhu et al., 2012). We recovered $10 \mathrm{MeC}_{16: 0}$ in the present study, which is characteristic of the lipid profile of M. oxyfera (Kool et al., 2012). Still, more concrete evidence, such as the recovery of specific gene markers of M. oxyfera (Luesken et al., 2011), is needed to confirm the presence of $M$. oxyfera in surface crusts. More recently, gammaproteobacterial (Type I) methanotrophs Methylomonas denitrificans and Methylomicrobium album have been reported to be able to oxidize methane under hypoxia using oxidized nitrogen as electron acceptor (Kits et al., 2015a; Kits et al., 2015b). The involvement of such a process would be consistent with the high proportion of $\mathrm{C}_{16}$ PLFAs recovered from $\mathrm{NO}_{3}{ }^{-}$and $\mathrm{NO}_{2}{ }^{-}$ treatments, and the genera Methylomonas and Methylomicrobium are widespread (Knief, 2015) and were indeed present in surface crusts (Duan et al., 2014). However, there was no direct evidence in the present study to evaluate the presence of these specific strains. 


\section{In-situ $\mathrm{O}_{2}$ and $\mathrm{N}_{2} \mathrm{O}$ Distribution and Implications for $\mathrm{CH}_{4}$ Oxidation}

Oxygen distribution in surface crusts vary over short distances, as shown in this and other studies (Hansen et

al., 2009; Nielsen et al., 2010). Despite this variation, the depth of $\mathrm{O}_{2}$ penetration is generally shallow and was never more than $25 \%$ of the thickness of the crust (Nielsen et al., 2010). The restriction of significant $\mathrm{O}_{2}$ penetration is likely due to surface crusts being a floating organic structure on top of liquid slurry, where the bottom of the crust is always saturated, while aerobic processes actively consume $\mathrm{O}_{2}$ in upper layers. Nielsen et al. (2010) proposed that trapping of gases formed in the slurry could elevate the crust above the liquid slurry phase and, as a result, improve $\mathrm{O}_{2}$ penetration. Measurements of $\mathrm{O}_{2}$ at a fixed depth over $48 \mathrm{~h}$ did indicate gas pockets that lifted the crust, but they were intermittently deflated (Supplemental Fig. S3). Structural voids in the crusts, such as pores and crevices, could also provide access for $\mathrm{O}_{2}$ to deeper parts of the crusts, and weather conditions such as precipitation and drought will influence $\mathrm{O}_{2}$ permeability by altering the wetness of the crust (Hansen et al., 2009).

The present study observed $\mathrm{N}_{2} \mathrm{O}$ levels as high as $100 \mu \mathrm{mol} \mathrm{L}^{-1}$, which was far above the $\mathrm{N}_{2} \mathrm{O}$ concentrations commonly found in other environments. For example, Baral et al. (2014) and Zhou et al. (2016) reported $\mathrm{N}_{2} \mathrm{O}$ concentrations of $<5 \mu \mathrm{mol} \mathrm{L} \mathrm{L}^{-1}$ near the soil surface. Careful examination of potential interferences to the microsensor is therefore warranted. Surface crusts may contain up to $300 \mu \mathrm{mol} \mathrm{L} \mathrm{L}^{-1}$ of $\mathrm{H}_{2} \mathrm{~S}$ (Nielsen et al., 2010), and $\mathrm{H}_{2} \mathrm{~S}$ is known to affect the signal of $\mathrm{N}_{2} \mathrm{O}$ microsensors. However, the microsensor used here is equipped with an alkaline oxygen guard which converts incoming $\mathrm{H}_{2} \mathrm{~S}$ to ionic forms, and this offers some protection to the cathode from $\mathrm{H}_{2} \mathrm{~S}$ (Andersen et al., 2001). With the same type of microsensor used in this study, Andersen et al. (2001) found a reduction in the sensitivity towards $\mathrm{N}_{2} \mathrm{O}$ with increasing concentrations of $\mathrm{H}_{2} \mathrm{~S}$ up to $350 \mu \mathrm{mol} \mathrm{L} \mathrm{L}^{-1}$, indicating that any $\mathrm{H}_{2} \mathrm{~S}$ interference would result in lower, not higher, $\mathrm{N}_{2} \mathrm{O}$ readings. Therefore, the high $\mathrm{N}_{2} \mathrm{O}$ concentrations observed were not likely to be a result of $\mathrm{H}_{2} \mathrm{~S}$ interference. In the above mentioned studies where soil $\mathrm{N}_{2} \mathrm{O}$ concentrations were $<5 \mu \mathrm{mol} \mathrm{L}^{-1}$, the corresponding $\mathrm{N}_{2} \mathrm{O}$ emissions were 3.6 and $25 \mu \mathrm{mol} \mathrm{m}{ }^{-2} \mathrm{~h}^{-1}$ (Baral et al., 2014; Zhou et al., 2016). For livestock slurry with surface crusts, $\mathrm{N}_{2} \mathrm{O}$ emissions as high as $393-1,429 \mu \mathrm{mol} \mathrm{m} \mathrm{m}^{-2} \mathrm{~h}^{-1}$ have been reported (Hansen et al., 2009; 
Sommer et al., 2000). Considering the relationship between $\mathrm{N}_{2} \mathrm{O}$ concentration and emission, $\mathrm{N}_{2} \mathrm{O}$ concentrations up to $100 \mu \mathrm{mol} \mathrm{L}^{-1}$ in surface crusts seem plausible.

Maximum $\mathrm{N}_{2} \mathrm{O}$ accumulation occurred near the oxic-anoxic interface in most cases, and therefore both nitrification and denitrification were potential sources of $\mathrm{N}_{2} \mathrm{O}$ (Braker and Conrad, 2011). Law et al. (2012) found a correlation between $\mathrm{N}_{2} \mathrm{O}$ production and ammonia oxidation rate, possibly as a result of nitrifier denitrification to conserve $\mathrm{O}_{2}$ or prevent $\mathrm{NO}_{2}{ }^{-}$toxicity (Lawton et al., 2013), and similar mechanisms could lead to $\mathrm{N}_{2} \mathrm{O}$ accumulation via ammonia oxidation in surface crusts. At or below oxic-anoxic interfaces, incomplete heterotrophic denitrification was likely the main source of $\mathrm{N}_{2} \mathrm{O}$ due to intolerance of $\mathrm{N}_{2} \mathrm{O}$ reductase towards trace $\mathrm{O}_{2}$ (Thomson et al., 2012). Nitrous oxide could also be released as a terminal product from methane oxidation coupled with partial denitrification by M. denitrificans (Kits et al., 2015b) and M. album (Kits et al., 2015a; Nyerges et al., 2010), which can be enabled by hypoxia developed at the oxic-anoxic interfaces. Denitrification could also act as a sink for $\mathrm{NO}_{3}{ }^{-}$or, particularly, $\mathrm{NO}_{2}{ }^{-}$which is a strong inhibitor of aerobic methane oxidation. The ubiquitous presence of $\mathrm{N}_{2} \mathrm{O}$ in the surface crusts indicated active transformations of $\mathrm{N}$ species which could interfere with methane oxidation. Yet, as seen from the incubation experiments, the effect of $\mathrm{N}$ species on $\mathrm{MOB}$ may be either inhibitory or stimulatory depending on other factors. Moreover, Type I MOB utilizing $\mathrm{NO}_{2}^{-}$and/or $\mathrm{NO}_{3}{ }^{-}$for methane oxidation are presumably more resilient to $\mathrm{N}$ inhibition than others (Zhu et al., 2016). In support of this, M. denitrificans and M. album have been shown to tolerate and grow under $10 \mathrm{mM} \mathrm{NO}_{3}{ }^{-}$(Kits et al., 2015b) and $2.5 \mathrm{mM} \mathrm{NO}_{2}^{-}$(Nyerges et al., 2010), respectively. Also, $\mathrm{Hu}$ and $\mathrm{Lu}$ (2015) found that, while $\mathrm{NH}_{4}{ }^{+}$and $\mathrm{NO}_{3}{ }^{-}$both stimulated Type I MOB as determined from pmoA gene copy numbers, Type II MOB were inhibited by $\mathrm{NH}_{4}{ }^{+}$as concentrations 349 increased.

350 Clearly, various physio-chemical and biological properties are involved in regulating methane oxidation in surface crust. Firstly, the heterogeneous structure of the crust adds complexity to the distribution of gases. Secondly, there are complex interactions between $\mathrm{CH}_{4}$ and $\mathrm{O}_{2}$ levels, and inorganic $\mathrm{N}$ species and concentration, with respect to methanotrophic activity. In parts of the crust where $\mathrm{CH}_{4}$ availability is 
354 relatively low, moderate $\mathrm{O}_{2}$ limitation probably has little impact on aerobic methane oxidation activity, 355 whereas $\mathrm{N}$ inhibition could be significant depending on $\mathrm{N}$ species and concentration. In contrast, in parts of 356 the crust with high $\mathrm{CH}_{4}$ availability, $\mathrm{O}_{2}$ limitation is likely the main control of aerobic methane oxidation, and 357 inhibition due to inorganic $\mathrm{N}$ is only important where $\mathrm{O}_{2}$ is not limiting.

\section{Conclusions}

359 Microsensor measurements of in situ $\mathrm{O}_{2}$ and $\mathrm{N}_{2} \mathrm{O}$ profiles revealed shallow penetration of $\mathrm{O}_{2}$ into slurry

360 surface crusts and active $\mathrm{N}$ transformations around oxic-anoxic interfaces. Laboratory incubations suggested 361 that $\mathrm{O}_{2}$ availability was more important to high-concentration than low-concentration methane oxidation, 362 and there were complex interactions between inorganic $\mathrm{N}$ and $\mathrm{O}_{2}$ limitation. The incorporation of ${ }^{13} \mathrm{C}$ from $363 \mathrm{CH}_{4}$ into membrane PLFAs indicated that both Type I and Type II MOB were actively involved in methane 364 oxidation, but with Type I MOB dominating the activity at high $\mathrm{CH}_{4}$ concentrations. These observations 365 together imply that manipulation of storage conditions to increase headspace $\mathrm{CH}_{4}$ concentration, as 366 proposed by Petersen and Miller (2006), could stimulate methane oxidation by Type I MOB in the upper 367 parts of the crust where $\mathrm{O}_{2}$ is non-limiting and mineral $\mathrm{N}$ availability low.

\section{Acknowledgements}

369 This study was partly funded by the Danish Agency for Science, Technology and Innovation. We thank Bodil 370 Stensgaard for technical assistance, and Kristian Kristensen for statistical support. 


\section{References}

Acha, V., J. Alba and F. Thalasso. 2002. The absolute requirement for carbon dioxide for aerobic methane oxidation by a methanotrophic-heterotrophic soil community of bacteria. Biotechnology Letters 24: 675-679. doi:10.1023/a:1015265530501.

Amaral, J.A., C. Archambault, S.R. Richards and R. Knowles. 1995. Denitrification associated with groups I and II methanotrophs in a gradient enrichment system. FEMS Microbiology Ecology 18: 289-298.

Amaral, J.A. and R. Knowles. 1995. Growth of methanotrophs in methane and oxygen counter gradients. FEMS Microbiology Letters 126: 215-220. doi:10.1111/j.1574-6968.1995.tb07421.x.

Andersen, K., T. Kjær and N.P. Revsbech. 2001. An oxygen insensitive microsensor for nitrous oxide. Sensors and Actuators B: Chemical 81: 42-48. doi:http://dx.doi.org/10.1016/\$0925-4005(01)00924-8.

Baral, K.R., A.G. Thomsen, J.E. Olesen and S.O. Petersen. 2014. Controls of nitrous oxide emission after simulated cattle urine deposition. Agriculture, Ecosystems \& Environment 188: 103-110. doi:http://dx.doi.org/10.1016/j.agee.2014.02.029.

Bodelier, P.L.E. 2011. Interactions between nitrogenous fertilizers and methane cycling in wetland and upland soils. Current Opinion in Environmental Sustainability 3: 379-388. doi:http://dx.doi.org/10.1016/j.cosust.2011.06.002.

Bodelier, P.L.E., M.-J. Bar Gillisen, K. Hordijk, J.S. Sinninghe Damste, W.I.C. Rijpstra, J.A.J. Geenevasen, et al. 2009. A reanalysis of phospholipid fatty acids as ecological biomarkers for methanotrophic bacteria. ISME J 3: 606-617. doi:10.1038/ismej.2009.6.

Bodelier, P.L.E. and H.J. Laanbroek. 2004. Nitrogen as a regulatory factor of methane oxidation in soils and sediments. FEMS Microbiology Ecology 47: 265-277. doi:10.1016/s0168-6496(03)00304-0.

Bollmann, A. and R. Conrad. 1998. Influence of $\mathrm{O} 2$ availability on NO and N2O release by nitrification and denitrification in soils. Global Change Biology 4: 387-396. doi:10.1046/j.1365-2486.1998.00161.x.

Bosse, U., P. Frenzel and R. Conrad. 1993. Inhibition of methane oxidation by ammonium in the surface layer of a littoral sediment. Fems Microbiology Ecology 13: 123-134. doi:10.1016/0168-6496(93)90030-b.

Braker, G. and R. Conrad. 2011. Chapter 2: Diversity, Structure, and Size of $\mathrm{N}_{2} \mathrm{O}-$ Producing Microbial Communities in Soils - What Matters for Their Functioning? In: S. S. Allen I. Laskin and M. G. Geoffrey, editors, Advances in Applied Microbiology. Academic Press. p. 33-70.

Broecker, W.S. and T.H. Peng. 1974. Gas exchange rates between air and sea. Tellus 26: 21-35. doi:10.1111/j.2153-3490.1974.tb01948.x.

Cai, Z.C. and X.Y. Yan. 1999. Kinetic model for methane oxidation by paddy soil as affected by temperature, moisture and $\mathrm{N}$ addition. Soil Biology \& Biochemistry 31: 715-725.

Carlsen, H.N., L. Joergensen and H. Degn. 1991. Inhibition by ammonia of methane utilization in Methylococcus capsulatus (Bath). Applied Microbiology and Biotechnology 35: 124-127. doi:10.1007/bf00180649.

Damgaard, L.R. and N.P. Revsbech. 1997. A Microscale Biosensor for Methane Containing Methanotrophic Bacteria and an Internal Oxygen Reservoir. Analytical Chemistry 69: 2262-2267. doi:10.1021/ac9611576.

De Beer, D., A. Schramm, C.M. Santegoeds and M. Kuhl. 1997. A nitrite microsensor for profiling environmental biofilms. Applied and Environmental Microbiology 63: 973-977.

De Beer, D., J.-P.R.A. Sweerts and J.C. van den Heuvel. 1991. Microelectrode measurement of ammonium profiles in freshwater sediments. FEMS Microbiology Letters 86: 1-6. doi:10.1111/j.15746968.1991.tb04789.x. 
De Visscher, A., D. Thomas, P. Boeckx and O. Van Cleemput. 1999. Methane Oxidation in Simulated Landfill Cover Soil Environments. Environmental Science \& Technology 33: 1854-1859. doi:10.1021/es9900961.

Duan, Y.-F., W. Abu Al-Soud, A. Brejnrod , S.J. Sørensen, L. Elsgaard, S.O. Petersen, et al. 2014. Methanotrophs, methanogens and microbial community structure in livestock slurry surface crusts. Journal of Applied Microbiology 117: 1066-1078. doi:10.1111/jam.12584.

Duan, Y.-F., L. Elsgaard and S.O. Petersen. 2013. Inhibition of methane oxidation in a slurry surface crust by inorganic N: An incubation study. Journal of Environmental Quality 42: 507-515. doi:10.2134/jeq2012.0230.

Dunfield, P. and R. Knowles. 1995. Kinetics of inhibition of methane oxidation by nitrate, nitrite, and ammonium in a humisol. Applied and Environmental Microbiology 61: 3129-3135.

Ettwig, K.F., T.v. Alen, K.T.v.d. Pas-Schoonen, M.S.M. Jetten and M. Strous. 2009. Enrichment and molecular detection of denitrifying methanotrophic bacteria of the NC10 phylum. Applied and Environmental Microbiology 75: 3656-3662. doi:10.1128/aem.00067-09.

Ettwig, K.F., M.K. Butler, D. Le Paslier, E. Pelletier, S. Mangenot, M.M.M. Kuypers, et al. 2010. Nitrite-driven anaerobic methane oxidation by oxygenic bacteria. Nature 464: 543-548. doi:10.1038/nature08883.

Francesco, N.T., S. Mirella, R. Simone, F. Alessandro, F. Nuala and S. Pete. 2013. The FAOSTAT database of greenhouse gas emissions from agriculture. Environmental Research Letters 8: 015009.

Graham, D.W., J.A. Chaudhary, R.S. Hanson and R.G. Arnold. 1993. Factors affecting competition between type I and type II methanotrophs in two-organism, continuous-flow reactors. Microbial Ecology 25: 1-17. doi:10.1007/bf00182126.

Gulledge, J. and J.P. Schimel. 1998. Low-Concentration Kinetics of Atmospheric CH4 Oxidation in Soil and Mechanism of NH4+ Inhibition. Applied and Environmental Microbiology 64: 4291-4298.

Hansen, R.R., D.A. Nielsen, A. Schramm, L.P. Nielsen, N.P. Revsbech and M.N. Hansen. 2009. Greenhouse Gas Microbiology in Wet and Dry Straw Crust Covering Pig Slurry. Journal of Environmental Quality 38: 1311-1319. doi:10.2134/jeq2008.0336.

Hanson, R.S. and T.E. Hanson. 1996. Methanotrophic bacteria. Microbiological Reviews 60: 439-471.

Hu, A. and Y. Lu. 2015. The differential effects of ammonium and nitrate on methanotrophs in rice field soil. Soil Biology and Biochemistry 85: 31-38. doi:http://dx.doi.org/10.1016/j.soilbio.2015.02.033.

King, G.M. and S. Schnell. 1994. Ammonium and Nitrite Inhibition of Methane Oxidation by Methylobacter albus BG8 and Methylosinus trichosporium OB3b at Low Methane Concentrations. Applied and Environmental Microbiology 60: 3508-3513.

King, G.M. and S. Schnell. 1998. Effects of Ammonium and Non-Ammonium Salt Additions on Methane Oxidation by Methylosinus trichosporium OB3b and Maine Forest Soils. Applied and Environmental Microbiology 64: 253-257.

Kits, K.D., D.J. Campbell, A.R. Rosana and L.Y. Stein. 2015a. Diverse electron sources support denitrification under hypoxia in the obligate methanotroph Methylomicrobium album strain BG8. Frontiers in Microbiology 6: 1072. doi:10.3389/fmicb.2015.01072.

Kits, K.D., M.G. Klotz and L.Y. Stein. 2015b. Methane oxidation coupled to nitrate reduction under hypoxia by the Gammaproteobacterium Methylomonas denitrificans, sp. nov. type strain FJG1. Environmental Microbiology 17: 3219-3232. doi:10.1111/1462-2920.12772.

Knief, C. 2015. Diversity and Habitat Preferences of Cultivated and Uncultivated Aerobic Methanotrophic Bacteria Evaluated Based on pmoA as Molecular Marker. Frontiers in Microbiology 6. doi:10.3389/fmicb.2015.01346. 
Kool, D.M., B. Zhu, W.I.C. Rijpstra, M.S.M. Jetten, K.F. Ettwig and J.S. Sinninghe Damsté. 2012. Rare Branched Fatty Acids Characterize the Lipid Composition of the Intra-Aerobic Methane Oxidizer "Candidatus Methylomirabilis oxyfera". Applied and Environmental Microbiology 78: 8650-8656. doi:10.1128/aem.02099-12.

Larsen, L.H., N.P. Revsbech and S.J. Binnerup. 1996. A microsensor for nitrate based on immobilized denitrifying bacteria. Applied and Environmental Microbiology 62: 1248-1251.

Law, Y., B.-J. Ni, P. Lant and Z. Yuan. 2012. N2O production rate of an enriched ammonia-oxidising bacteria culture exponentially correlates to its ammonia oxidation rate. Water Research 46: 3409-3419. doi:10.1016/j.watres.2012.03.043.

Lawton, T.J., K.E. Bowen, L.A. Sayavedra-Soto, D.J. Arp and A.C. Rosenzweig. 2013. Characterization of a Nitrite Reductase Involved in Nitrifier Denitrification. Journal of Biological Chemistry 288: 2557525583. doi:10.1074/jbc.M113.484543.

Liu, L. and T.L. Greaver. 2009. A review of nitrogen enrichment effects on three biogenic GHGs: the CO2 sink may be largely offset by stimulated $\mathrm{N} 2 \mathrm{O}$ and $\mathrm{CH} 4$ emission. Ecology Letters 12: 1103-1117. doi:10.1111/j.1461-0248.2009.01351.x.

Luesken, F.A., B. Zhu, T.A. van Alen, M.K. Butler, M. Rodriguez Diaz, B. Song, et al. 2011. pmoA primers for detection of anaerobic methanotrophs. Applied and Environmental Microbiology. doi:10.1128/aem.02960-10.

Melse, R.W. and A.W. van der Werf. 2005. Biofiltration for Mitigation of Methane Emission from Animal Husbandry. Environmental Science \& Technology 39: 5460-5468. doi:10.1021/es048048q.

Nielsen, D.A., L.P. Nielsen, A. Schramm and N.P. Revsbech. 2010. Oxygen Distribution and Potential Ammonia Oxidation in Floating, Liquid Manure Crusts. J. Environ. Qual. 39: 1813-1820. doi:10.2134/jeq2009.0382.

Nielsen, D.A., A. Schramm, L.P. Nielsen and N.P. Revsbech. 2013. Seasonal Methane Oxidation Potential in Manure Crusts. Applied and Environmental Microbiology 79: 407-410. doi:10.1128/aem.02278-12.

Nyerges, G., S.-K. Han and L.Y. Stein. 2010. Effects of Ammonium and Nitrite on Growth and Competitive Fitness of Cultivated Methanotrophic Bacteria. Applied and Environmental Microbiology 76: 56485651. doi:10.1128/aem.00747-10.

Petersen, S. and P. Ambus. 2006. Methane Oxidation in Pig and Cattle Slurry Storages, and Effects of Surface Crust Moisture and Methane Availability. Nutrient Cycling in Agroecosystems 74: 1-11. doi:10.1007/s10705-005-3822-6.

Petersen, S.O., B. Amon and A. Gattinger. 2005. Methane Oxidation in Slurry Storage Surface Crusts. J. Environ. Qual. 34: 455-461. doi:10.2134/jeq2005.0455.

Petersen, S.O., P.S. Frohne and A.C. Kennedy. 2002. Dynamics of a Soil Microbial Community under Spring Wheat. Soil Science Society of America Journal 66: 826-833. doi:10.2136/sssaj2002.8260.

Petersen, S.O. and D.N. Miller. 2006. Greenhouse gas mitigation by covers on livestock slurry tanks and lagoons? Journal of the Science of Food and Agriculture 86: 1407-1411. doi:10.1002/jsfa.2543.

Petersen, S.O., M. Skov, P. Drøscher and A.P.S. Adamsen. 2009. Pilot Scale Facility To Determine Gaseous Emissions From Livestock Slurry During Storage. J. Environ. Qual. 38: 1560-1568. doi:10.2134/jeq2008.0376.

Qiu, Q., M. Noll, W.-R. Abraham, Y. Lu and R. Conrad. 2008. Applying stable isotope probing of phospholipid fatty acids and rRNA in a Chinese rice field to study activity and composition of the methanotrophic bacterial communities in situ. ISME J 2: 602-614. 
Revsbech, N.P. 2005. Analysis of Microbial Communities with Electrochemical Microsensors and Microscale Biosensors. In: R. L. Jared, editor Methods in Enzymology. Academic Press. p. 147-166.

Roslev, P., N. Iversen and K. Henriksen. 1997. Oxidation and assimilation of atmospheric methane by soil methane oxidizers. Applied and Environmental Microbiology 63: 874-880.

Sommer, S., S. Petersen, P. Sørensen, H. Poulsen and H. Møller. 2007. Methane and carbon dioxide emissions and nitrogen turnover during liquid manure storage. Nutrient Cycling in Agroecosystems 78: 27-36. doi:10.1007/s10705-006-9072-4.

Sommer, S.G., S.O. Petersen and H.T. Søgaard. 2000. Greenhouse Gas Emission from Stored Livestock Slurry. Journal of Environmental Quality 29: 744-751. doi:10.2134/jeq2000.00472425002900030009x.

Stein, L.Y. and M.G. Klotz. 2011. Nitrifying and denitrifying pathways of methanotrophic bacteria. Biochemical Society Transactions 39: 1826-1831. doi:10.1042/bst20110712.

Thomson, A.J., G. Giannopoulos, J. Pretty, E.M. Baggs and D.J. Richardson. 2012. Biological sources and sinks of nitrous oxide and strategies to mitigate emissions. Philosophical Transactions of The Royal Society B 367: 1157-1168. doi:10.1098/rstb.2011.0415.

Urmann, K., E.S. Norina, M.H. Schroth and J. Zeyer. 2007. Methanotrophic activity in a diffusive methane/oxygen counter-gradient in an unsaturated porous medium. Journal of Contaminant Hydrology 94: 126-138. doi:10.1016/j.jconhyd.2007.05.006.

Wang, Y., G. Zhu, H.R. Harhangi, B. Zhu, M.S.M. Jetten, C. Yin, et al. 2012. Co-occurrence and distribution of nitrite-dependent anaerobic ammonium and methane-oxidizing bacteria in a paddy soil. FEMS Microbiology Letters 336: 79-88. doi:10.1111/j.1574-6968.2012.02654.x.

Wang, Z.-P. and P. Ineson. 2003. Methane oxidation in a temperate coniferous forest soil: effects of inorganic N. Soil Biology and Biochemistry 35: 427-433. doi:10.1016/s0038-0717(02)00294-8.

Welte, C.U., O. Rasigraf, A. Vaksmaa, W. Versantvoort, A. Arshad, H.J.M. Op den Camp, et al. 2016. Nitrateand nitrite-dependent anaerobic oxidation of methane. Environmental Microbiology Reports 8: 941955. doi:10.1111/1758-2229.12487.

Whittenbury, R., K.C. Phillips and J.F. Wilkinson. 1970. Enrichment, Isolation and Some Properties of Methane-utilizing Bacteria. Journal of General Microbiology 61: 205-218. doi:10.1099/00221287-612-205.

Zhou, Z., X. Xu, Z. Bi, L. Li, B. Li and Z. Xiong. 2016. Soil concentration profiles and diffusion and emission of nitrous oxide influenced by the application of biochar in a rice-wheat annual rotation system. Environmental Science and Pollution Research 23: 7949-7961. doi:10.1007/s11356-015-5929-x.

Zhu, B., G. van Dijk, C. Fritz, A.J.P. Smolders, A. Pol, M.S.M. Jetten, et al. 2012. Anaerobic Oxidization of Methane in a Minerotrophic Peatland: Enrichment of Nitrite-Dependent Methane-Oxidizing Bacteria. Applied and Environmental Microbiology 78: 8657-8665. doi:10.1128/aem.02102-12.

Zhu, J., Q. Wang, M. Yuan, G.-Y.A. Tan, F. Sun, C. Wang, et al. 2016. Microbiology and potential applications of aerobic methane oxidation coupled to denitrification (AME-D) process: A review. Water Research 90: 203-215. doi:http://dx.doi.org/10.1016/j.watres.2015.12.020. 

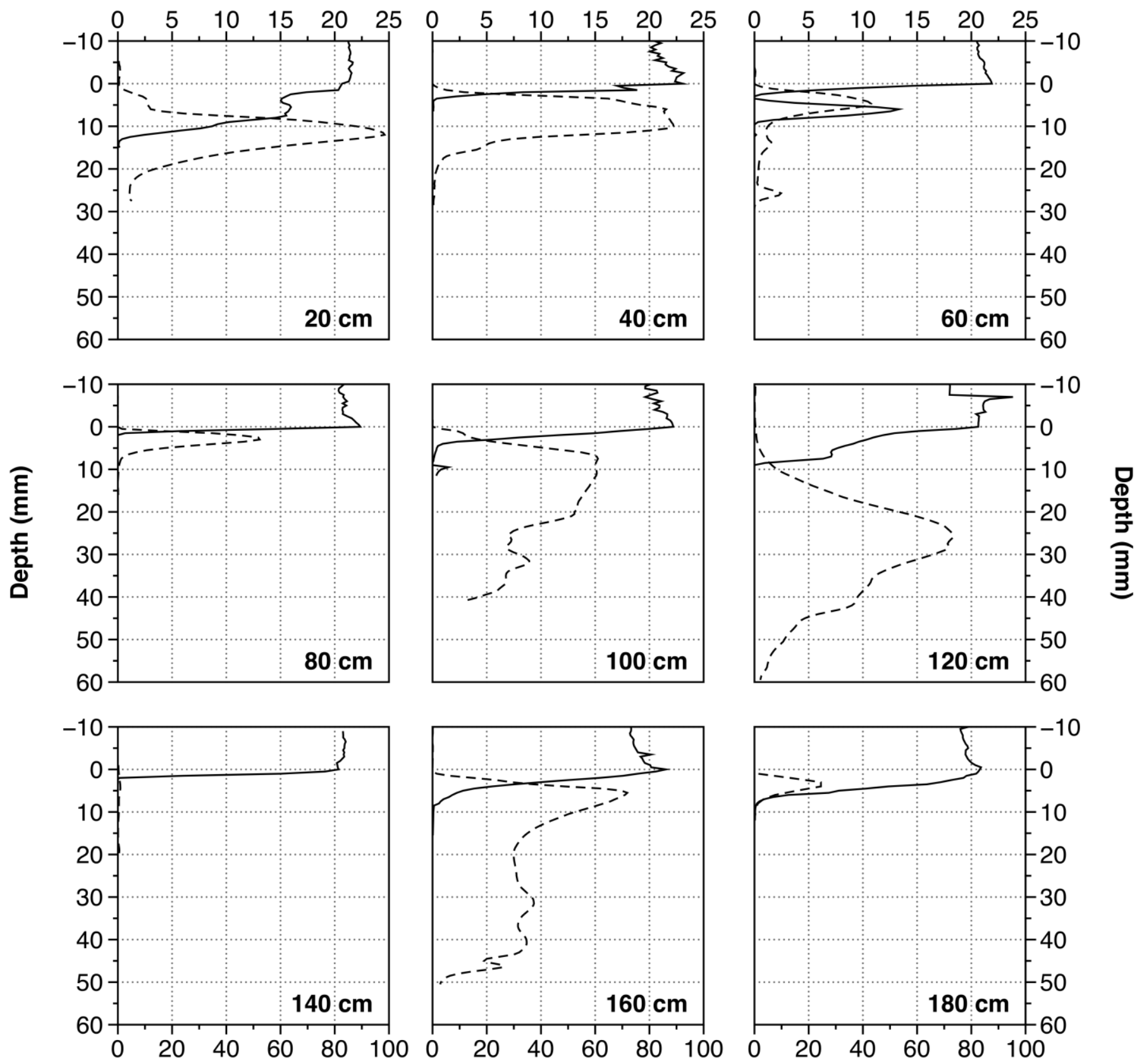

\section{---- $\mathrm{N}_{2} \mathrm{O}$ Concentration $\left(\mu \mathrm{mol} \mathrm{L} \mathrm{L}^{-1}\right)$}

Figure 1: Profiles of oxygen $\left(\mathrm{O}_{2}\right.$, solid line, top X-axis) and nitrous oxide $\left(\mathrm{N}_{2} \mathrm{O}\right.$, dashed line, bottom $X$-axis $)$ profiles in a surface crust measured using microsensors at $20 \mathrm{~cm}$ intervals along the 200-cm diameter of a slurry storage tank. Distances of the sampling points from the edge of the tank are indicated on the bottom-right corner of each panel. Oxygen was traced to a depth of $30 \mathrm{~mm}$ in all cases; $\mathrm{N}_{2} \mathrm{O}$ was traced to a depth of $30 \mathrm{~mm}$ at $20-80 \mathrm{~cm}$ and to a depth of $60 \mathrm{~mm}$ at $100-180 \mathrm{~cm}$. 

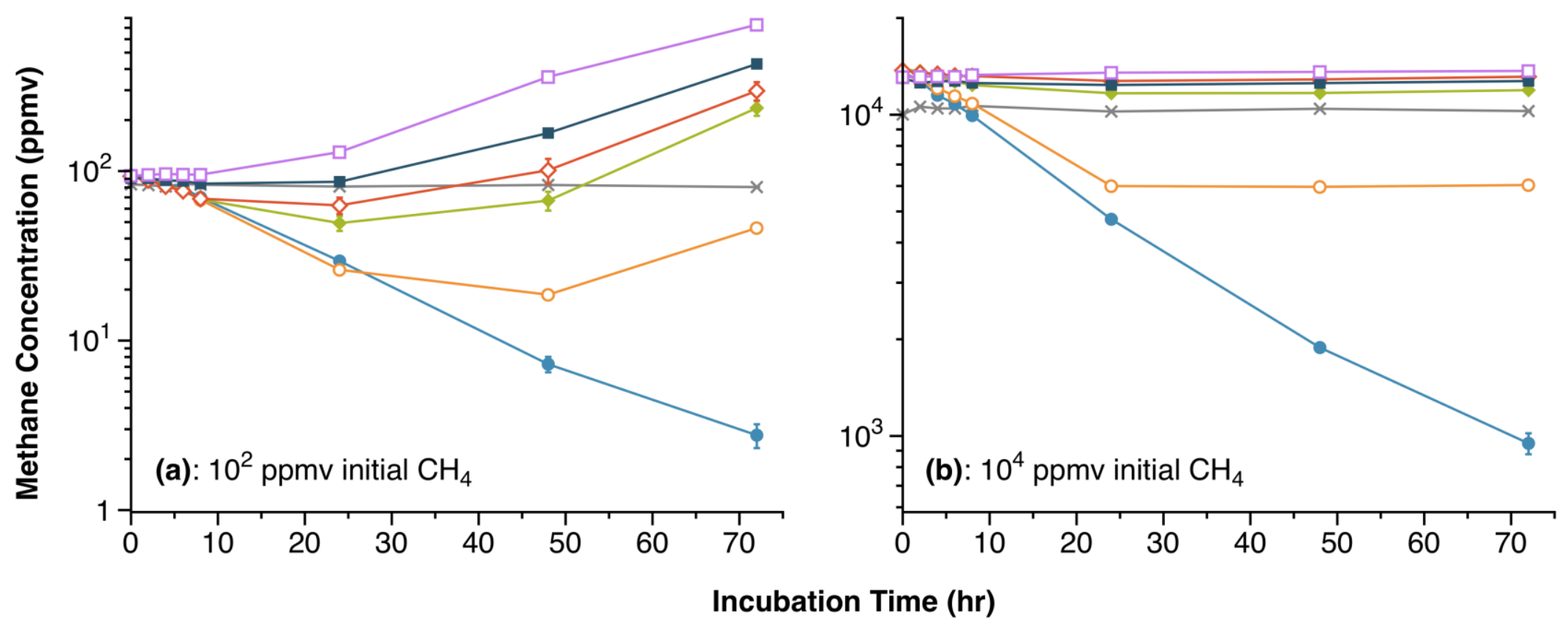

\begin{tabular}{|l|}
\hline Oxygen \\
-- Blank Control \\
$--20 \%$ \\
$--5 \%$ \\
$--3 \%$ \\
$--2 \%$ \\
$--1 \%$ \\
$-\square-0 \%$ \\
\hline
\end{tabular}

Figure 2: Dynamics of $\mathrm{CH}_{4}$ concentrations during a 72-h incubation of slurry surface crusts with initial $\mathrm{O}_{2}$ concentrations of $20,5,3,2,1$, and $0 \%$, and with initial $\mathrm{CH}_{4}$ concentrations of $10^{2} \mathrm{ppmv}(\mathrm{a})$ and $10^{4} \mathrm{ppmv}$ (b). Blank control contained $20 \%$ initial headspace $\mathrm{O}_{2}$ and no crust material. Each point represents the mean of triplicate assays, and error bars show standard error. 


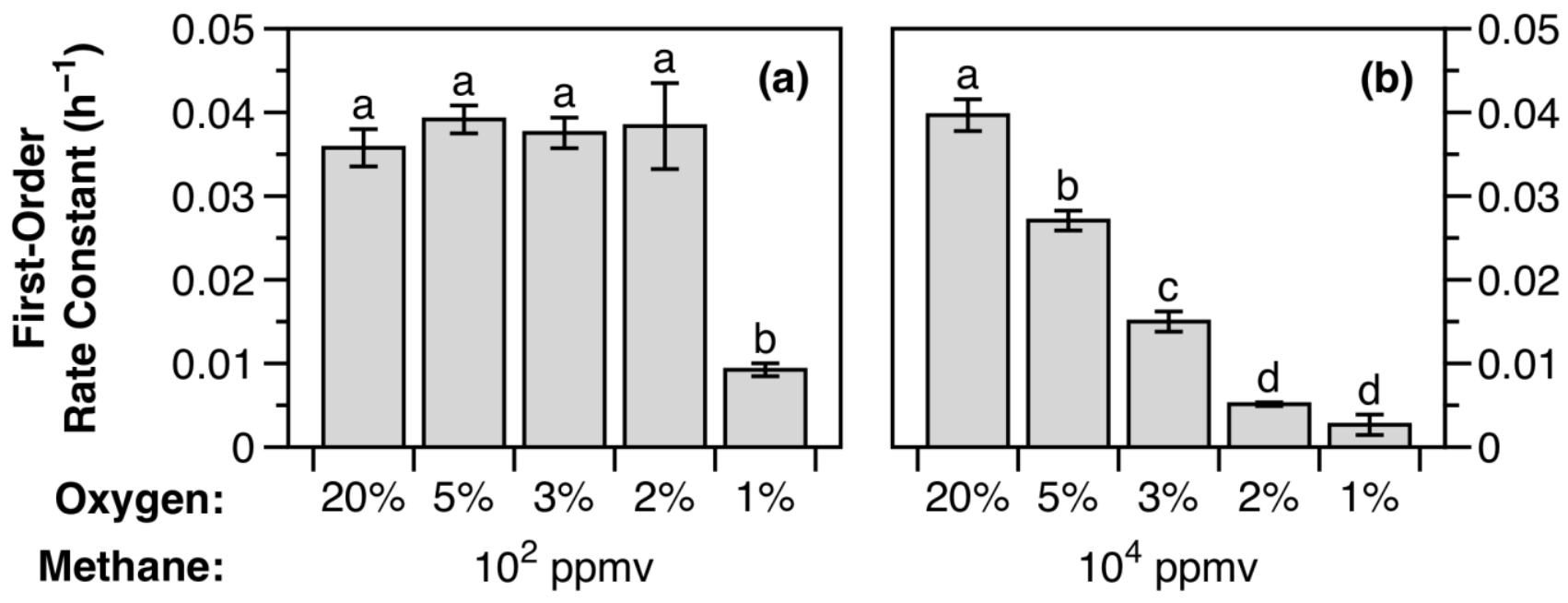

Figure 3: First-order rate constants of potential $\mathrm{CH}_{4}$ oxidation under different $\mathrm{O}_{2}$ and $\mathrm{CH}_{4}$ concentrations during the first $8 \mathrm{~h}$ of incubation. The bars show the mean of triplicate assays, and the error bars show standard error. For each $\mathrm{CH}_{4}$ concentration, bars denoted with the same letter on top are not significantly different at $\alpha=0.05$. 


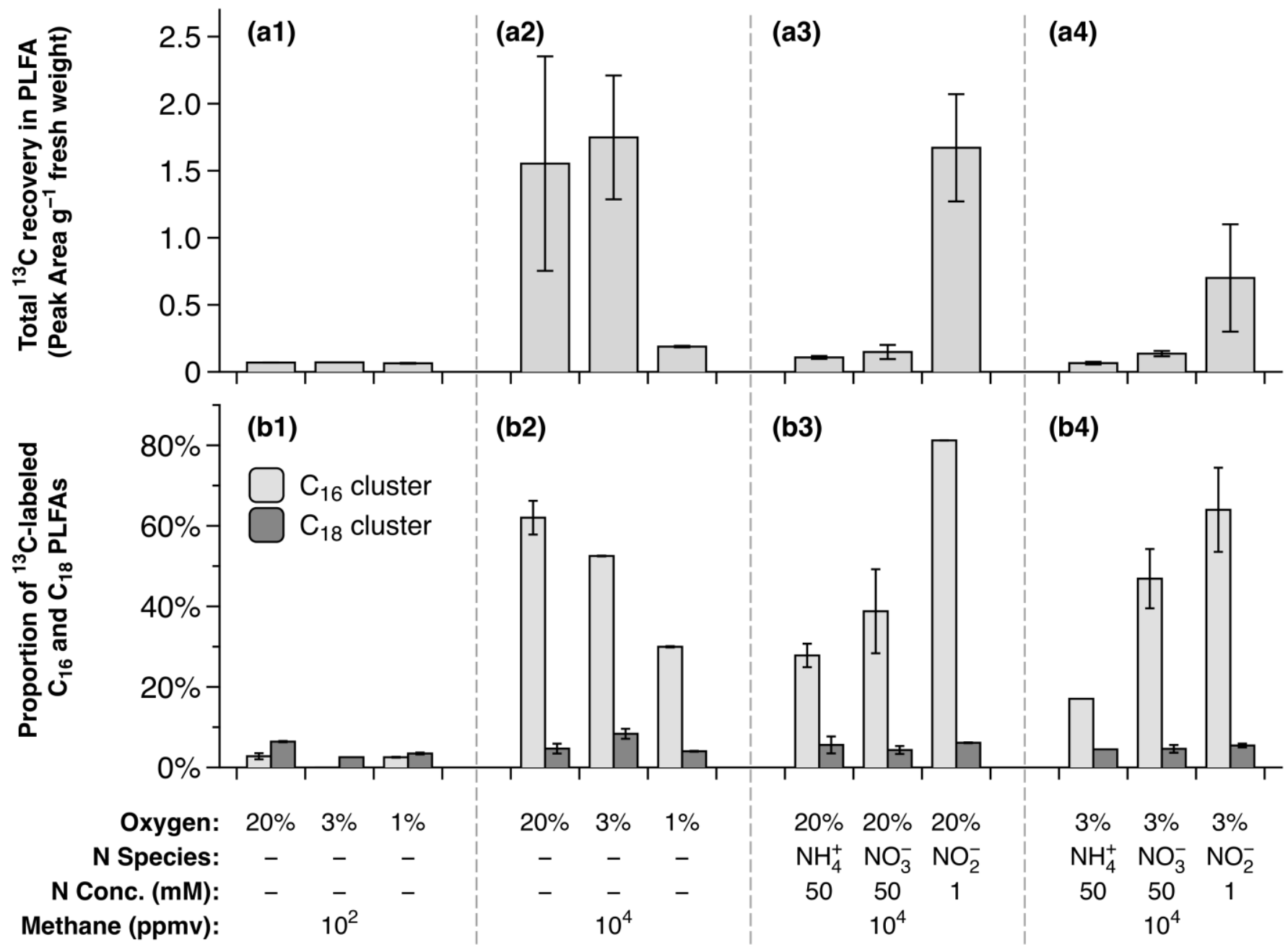

Figure 4: Total recovery of ${ }^{13} \mathrm{C}$ in PLFA (expressed as peak area per gram fresh crust) derived from incubation of surface crusts with ${ }^{13} \mathrm{CH}_{4}$ (a1-a4), and proportions of ${ }^{13} \mathrm{C}$ incorporation into PLFA belonging to $\mathrm{C}_{16}$ or $\mathrm{C}_{18}$ clusters (b1b4) at different combinations of $\mathrm{O}_{2}, \mathrm{CH}_{4}$, and inorganic $\mathrm{N}$ availability. Data shown are means and standard errors of two replicates. 
Table 1: Selected chemical properties of various livestock slurries and surface crusts from previous studies.

\begin{tabular}{|c|c|c|c|c|c|}
\hline \multirow{3}{*}{ Sample } & \multicolumn{3}{|c|}{ Surface Crust } & \multicolumn{2}{|c|}{ Slurry } \\
\hline & $\mathrm{NH}_{4}^{+}$ & $\mathrm{NO}_{3}^{-}$ & $\mathrm{NO}_{2}^{-}$ & $\mathrm{pH}$ & $\mathrm{NH}_{4}^{+}$ \\
\hline & $\mu \mathrm{mol} \mathrm{kg}{ }^{-1} \mathrm{WW}^{*}$ & $\mu \mathrm{mol} \mathrm{kg}{ }^{-1} \mathrm{WW}$ & $\mu \mathrm{mol} \mathrm{kg}{ }^{-1} \mathrm{WW}$ & & $\mathrm{mM}$ \\
\hline $\begin{array}{l}\text { Cattle slurry surface crusts developed for } 3 \\
\text { years (Duan et al., 2013) }\end{array}$ & 116.3 & 370.9 & n.a." & n.a. & n.a. \\
\hline $\begin{array}{l}\text { Various cattle and swine slurries and surface } \\
\text { crusts (Nielsen et al., 2010) }\end{array}$ & n.a. & $7-3,602$ & $2-98,000$ & $6.96-7.7$ & 84-205 \\
\hline $\begin{array}{l}\text { Surface crusts of various dryness (Hansen et } \\
\text { al., 2009) }\end{array}$ & n.a. & $290-35,000$ & $80-1,990$ & 7.7 & 175 \\
\hline $\begin{array}{l}\text { Various cattle and swine slurries (Sommer et } \\
\text { al., 2007) }\end{array}$ & n.a. & n.a. & n.a. & n.a. & $79-257$ \\
\hline Surface crusts (Petersen et al., 2006) & $1,432-54,923$ & $91-16,378$ & $3-50$ & $7.13-8.89$ & $1.7-69$ \\
\hline Digested cattle slurry (Clemens et al., 2006) & n.a. & n.a. & n.a. & $7.4-7.8$ & $85-127$ \\
\hline
\end{tabular}

*WW, wet weight.

\# n.a., value not reported. 
Table 2: Combinations of $\mathrm{CH}_{4}, \mathrm{O}_{2}$, and inorganic $\mathrm{N}$ amendments used in this study. The values indicate the number of replicates prepared. Treatments marked with asterisks $\left({ }^{*}\right)$ were used for analysis of ${ }^{13} \mathrm{C}$-labelled phosphate lipid fatty acids (PLFAs).

\begin{tabular}{|c|c|c|c|c|c|c|c|c|c|c|c|c|c|c|}
\hline \multirow{2}{*}{\multicolumn{2}{|c|}{$\begin{array}{l}\text { N Species and } \\
\text { Concentrations }\end{array}$}} & \multirow{2}{*}{$\begin{array}{r}\mathrm{CH}_{4}: \\
\mathrm{O}_{2}:\end{array}$} & \multicolumn{6}{|c|}{$10^{2} \mathrm{ppmv}$} & \multicolumn{6}{|c|}{$10^{4} \mathrm{ppmv}$} \\
\hline & & & $0 \%$ & $1 \%$ & $2 \%$ & $3 \%$ & $5 \%$ & $20 \%$ & $0 \%$ & $1 \%$ & $2 \%$ & $3 \%$ & $5 \%$ & $20 \%$ \\
\hline None & & & 3 & 3* & 3 & $3 *$ & 3 & 3* & 3 & $3 *$ & 3 & $3 *$ & 3 & $3 *$ \\
\hline \multirow[t]{2}{*}{$\mathrm{NH}_{4}{ }^{+}$} & $10 \mathrm{mM}$ & & & & & 2 & & 2 & & & & 2 & & 2 \\
\hline & $50 \mathrm{mM}$ & & & & & 2 & & 2 & & & & $2^{*}$ & & $2 *$ \\
\hline \multirow[t]{2}{*}{$\mathrm{NO}_{3}^{-}$} & $10 \mathrm{mM}$ & & & & & 2 & & 2 & & & & 2 & & 2 \\
\hline & $50 \mathrm{mM}$ & & & & & 2 & & 2 & & & & $2^{*}$ & & $2^{*}$ \\
\hline $\mathrm{NO}_{2}^{-}$ & $1 \mathrm{mM}$ & & & & & 2 & & 2 & & & & $2^{*}$ & & $2 *$ \\
\hline
\end{tabular}


Table 3: First-order rate constants $\left(\mathrm{h}^{-1}\right)$ of $\mathrm{CH}_{4}$ oxidation in slurry surface crust samples under different $\mathrm{O}_{2}$ concentrations and $\mathrm{N}$ amendments. Numbers in parentheses indicate relative activity (the ratio of the treatment activity as compared to the activity of the $\mathrm{N}$-free control). Under each $\mathrm{CH}_{4}$ concentration, values followed by the same letter are not significantly different at $\alpha=0.05$.

\begin{tabular}{|c|c|c|c|c|c|}
\hline \multirow{3}{*}{\multicolumn{2}{|c|}{$\begin{array}{l}\text { N Species and } \\
\text { Concentrations }\end{array}$}} & \multicolumn{4}{|c|}{ First-Order Rate Constants $\left(\mathrm{h}^{-1}\right)$} \\
\hline & & \multicolumn{2}{|c|}{$10^{2} \mathrm{ppmv} \mathrm{CH}_{4}$} & \multicolumn{2}{|c|}{$10^{4} \mathrm{ppmv} \mathrm{CH}_{4}$} \\
\hline & & $20 \% \mathrm{O}_{2}$ & $3 \% \mathrm{O}_{2}$ & $20 \% \mathrm{O}_{2}$ & $3 \% \mathrm{O}_{2}$ \\
\hline None & & $0.036(1.00) \mathrm{a}$ & $0.037(1.00) \mathrm{a}$ & $0.040(1.00) b$ & $0.016(1.00) \mathrm{e}$ \\
\hline \multirow[t]{2}{*}{$\mathrm{NH}_{4}^{+}$} & $10 \mathrm{mM}$ & $0.015(0.42) d$ & $0.010(0.27)$ ef & $0.031(0.78) \mathrm{c}$ & $0.017(1.06) \mathrm{e}$ \\
\hline & $50 \mathrm{mM}$ & $0.007(0.19) \mathrm{fg}$ & $0.005(0.14) \mathrm{g}$ & $0.013(0.33) \mathrm{e}$ & $0.005(0.31) f$ \\
\hline \multirow[t]{2}{*}{$\mathrm{NO}_{3}^{-}$} & $10 \mathrm{mM}$ & $0.029(0.81) b$ & $0.022(0.59) \mathrm{c}$ & $0.054(1.35) \mathrm{a}$ & $0.022(1.38) d$ \\
\hline & $50 \mathrm{mM}$ & $0.017(0.47) d$ & $0.013(0.35)$ de & $0.028(0.70) \mathrm{c}$ & $0.021(1.31) d$ \\
\hline $\mathrm{NO}_{2}^{-}$ & $1 \mathrm{mM}$ & $0.008(0.22) \mathrm{fg}$ & $0.008(0.22) \mathrm{fg}$ & $0.016(0.40) \mathrm{e}$ & $0.017(1.06) \mathrm{e}$ \\
\hline
\end{tabular}


Supplemental Material

\section{Methanotrophic activity in slurry surface crusts as influenced by $\mathrm{CH}_{4}, \mathrm{O}_{2}$, and inorganic $\mathrm{N}$}

Yun-Feng Duan ${ }^{1 *}$, Sabine Reinsch ${ }^{2 \#}$, Per Ambus ${ }^{2 \S}$, Lars Elsgaard ${ }^{1}$, and Søren O. Petersen ${ }^{1}$

${ }^{1}$ Department of Agroecology, Aarhus University, Blichers Allé 20, DK-8830 Tjele, Denmark

${ }^{2}$ Department of Chemical and Biochemical Engineering, Technical University of Denmark, Frederiksborgvej 399, DK-4000 Roskilde, Denmark

* Corresponding Author: Yun-Feng Duan, Department of Agroecology, Aarhus University, Blichers Allé 20, DK-8830 Tjele, Denmark; E-mail: Kevin.YF.Duan@gmail.com.

\# Present address: Centre for Ecology and Hydrology, Deiniol Rd, Bangor Gwynedd, LL57 2 UW, UK

$\S$ Present address: Department of Geosciences and Natural Resource Management, University of Copenhagen, $\emptyset$ ster Voldgade 10, DK-1350 Copenhagen, Denmark 


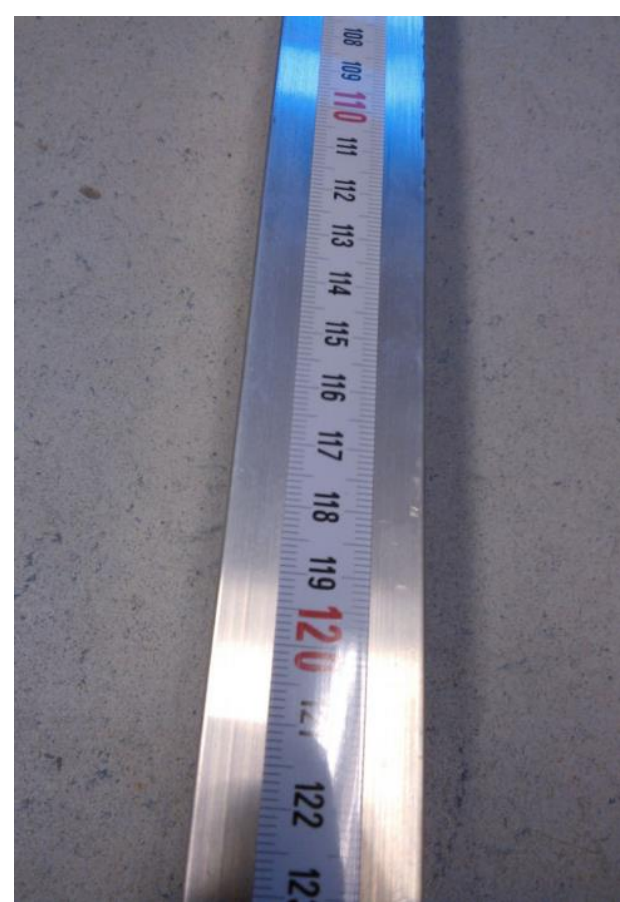

(a). The 200-cm long aluminum bar with distance marks.

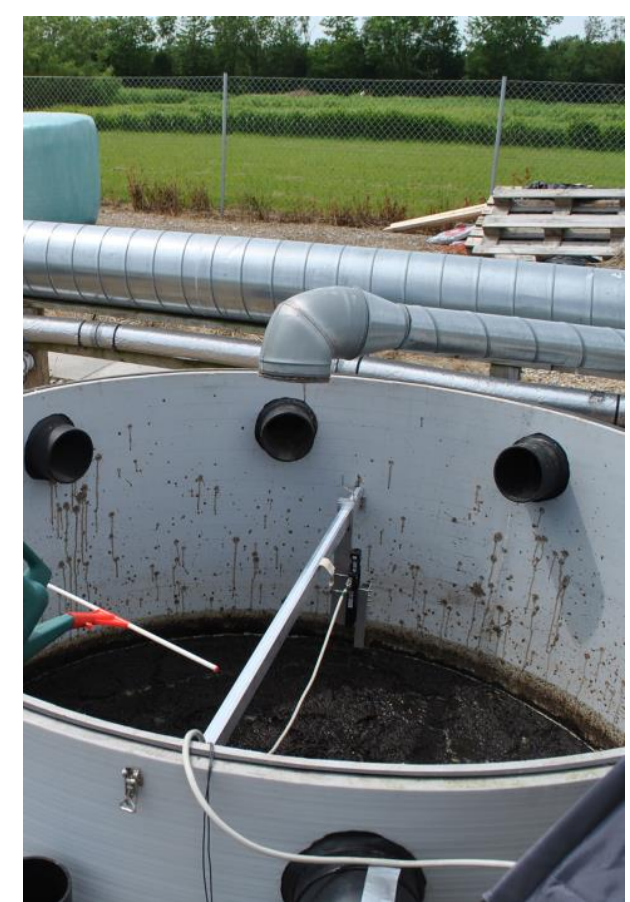

(b). The aluminum bar installed on the inner rim of the slurry tank.

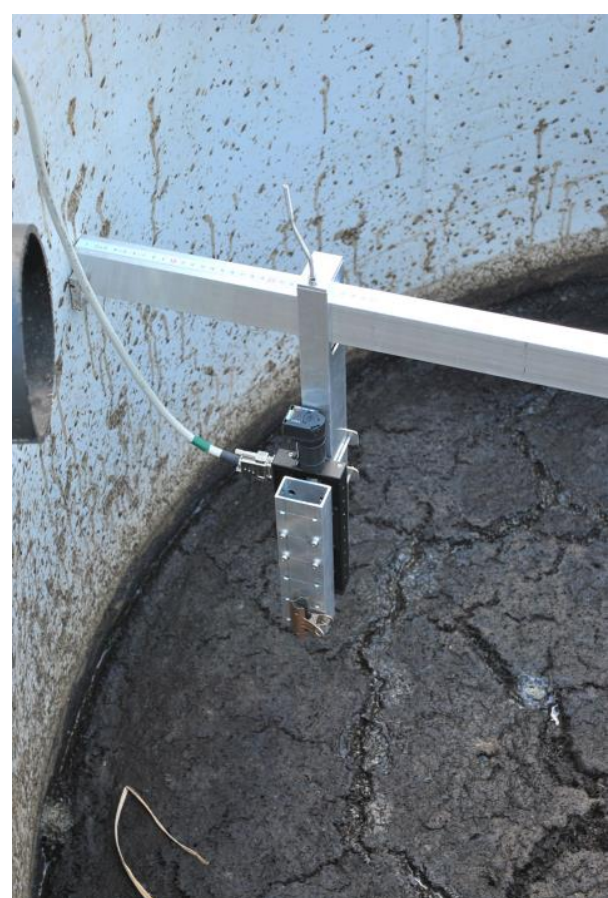

(c). The motorized micromanipulator mounted on the aluminum bar.

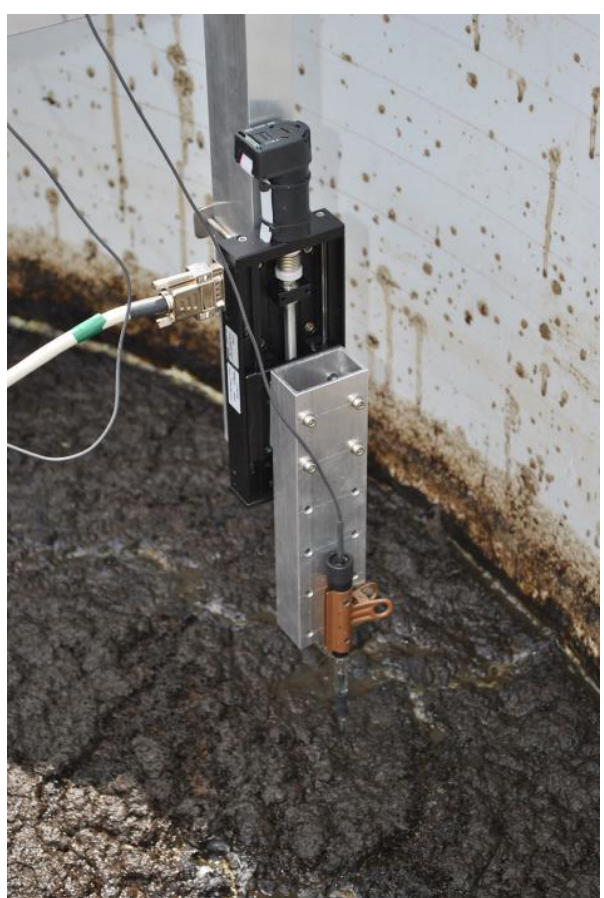

(d). The microsensor fixed to the micromanipulator.

Figure S1: Custom-made mounting system for in situ measurement of $\mathrm{O}_{2}$ and $\mathrm{N}_{2} \mathrm{O}$ profiles using microsensors.

A 200-cm long aluminum bar with mm-scale distance marks (a) was installed on the inner rim of the storage tank, approximately $40 \mathrm{~cm}$ above the surface crust (b). A computer-controlled motorized micromanipulator (Unisense, Aarhus, Denmark) capable of vertical movement was mounted on a custom-made rack, which could be moved manually along the length of the aluminum bar (c). The microsensor was fixed to the micromanipulator using a rubber-lined clamp (d). When installed at the initial position for measurement, the tip of the microsensor was approximately $1 \mathrm{~cm}$ above the surface of the crust. During measurements, a cover was placed loosely over the storage tank to avoid heating of the surface crust by direct insolation.

When measurement at one sampling point was completed, the microsensor was retreated to initial position and temporarily detached from the micromanipulator to protect the tip from breaking during movement, and reinstalled after the micromanipulator had been moved to the next sampling point. 


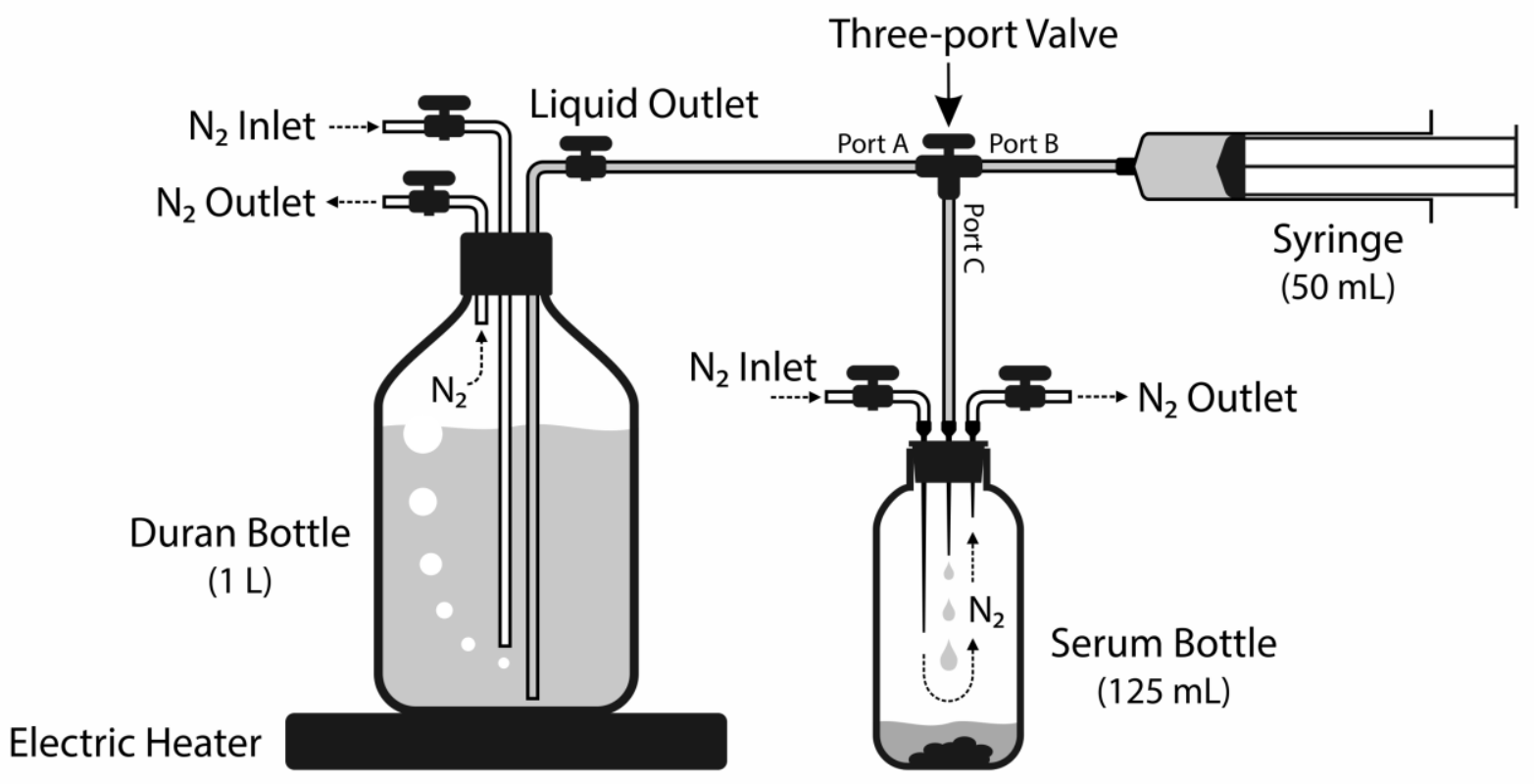

Figure S2: Diagram of the setup to prepare and distribute anoxic incubation medium.

A Duran bottle was modified to have three plastic tubes inserted through the cap: one as $\mathrm{N}_{2}$ inlet, one as $\mathrm{N}_{2}$ outlet, and the third as liquid outlet. The Duran bottle was filled with BS medium to ca. $70 \%$ of its volume and placed on an electric heater with the cap tightly secured. The BS medium was heated to the boiling point while bubbled with pure $\mathrm{N}_{2}$ for at least $30 \mathrm{~min}$, and then cooled to room temperature still under $\mathrm{N}_{2}$ bubbling. Then, the $\mathrm{N}_{2}$ outlet was closed and the liquid outlet valve was opened, and the entire tubing was flushed and filled with anoxic BS medium by the build-up of gas pressure inside the Duran bottle. When distributing BS medium to the serum bottle, a needle connected to pure $\mathrm{N}_{2}$ flow was first inserted into the serum bottle through the rubber stopper and then, a second needle was inserted as $\mathrm{N}_{2}$ outlet. The serum bottle was flushed with $\mathrm{N}_{2}$ for $10 \mathrm{sec}$, and then a third needle connected to the three-port valve was inserted. Ports $\mathrm{A}$ and $B$ of the three-port valve were opened while $C$ was closed, and the syringe was filled with $20 \mathrm{~mL}$ incubation medium. Then, ports $B$ and $C$ were opened and $A$ was closed and the incubation medium was injected from the syringe into the serum bottle while the bottle was being flushed by pure $N_{2}$. 


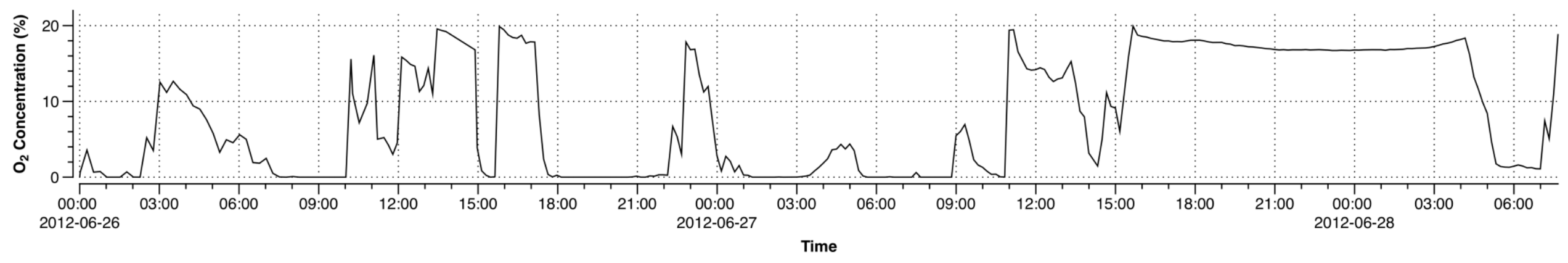

Figure S3: Dynamics of $\mathrm{O}_{2}$ concentration at a fixed depth in a surface crust over 48 hours. The storage tank was covered to eliminate wind effect but was passively ventilated. The microsensor was initially fixed in a position where the tip just touched the surface of the crust. Oxygen concentrations were measured every $10-15$ min as described in the manuscript. The peaks in $\mathrm{O}_{2}$ profile showed that the microsensor was alternately exposed to atmospheric $\mathrm{O}_{2}$ and more anaerobic conditions. This indicated that the surface of the crust periodically rose up and moved down, likely due to inflation and deflation of gas pockets underneath the crust. 
Table S1: Oxygen Consumption during $\mathrm{CH}_{4}$ oxidation at 10,000 ppmv initial $\mathrm{CH}_{4}$.

\begin{tabular}{llllll}
\hline \multicolumn{2}{c}{ Initial State (time 0) } & & \multicolumn{3}{c}{ After 8 h } \\
\cline { 1 - 2 } \cline { 5 - 6 } $\begin{array}{lllll}\text { Headspace } \mathrm{O}_{2} \\
(\%)\end{array}$ & $\begin{array}{l}\text { Dissolved } \mathrm{O}_{2} \\
(\mu \mathrm{M})\end{array}$ & & $\begin{array}{l}\mathrm{CH}_{4} \text { Consumed } \\
(\mu \mathrm{M})\end{array}$ & $\begin{array}{l}\mathrm{O}_{2} \text { Consumed } \\
(\mu \mathrm{M})\end{array}$ & $\begin{array}{l}\mathrm{O}_{2} \text { Remaining } \\
(\mu \mathrm{M})\end{array}$ \\
\hline 20 & 256.0 & & 4.92 & 9.84 & 246.2 \\
3 & 38.4 & 1.95 & 3.90 & 34.5 \\
1 & 12.8 & 0.57 & 1.14 & 11.7 \\
\hline
\end{tabular}

- Stoichiometry of $\mathrm{CH}_{4}$ oxidation is:

$$
\mathrm{CH}_{4}+(2-x) \mathrm{O}_{2} \longrightarrow(1-x) \mathrm{CO}_{2}+x \mathrm{CH}_{2} \mathrm{O}+(2-x) \mathrm{H}_{2} \mathrm{O}
$$

where $x$ is the fraction of carbon that is assimilated into biomass $\left(\mathrm{CH}_{2} \mathrm{O}\right)$ (Urmann et al., 2007).

Therefore, $\mathrm{CH}_{4}$ to $\mathrm{O}_{2}$ ratio in $\mathrm{CH}_{4}$ oxidation theoretically ranges between $1: 1$ (100\% C assimilation) and 1:2 (no $\mathrm{C}$ assimilation). In this calculation, we assumed maximum $\mathrm{O}_{2}$ consumption, i.e. a $\mathrm{CH}_{4}$ to $\mathrm{O}_{2}$ ratio of $1: 2$.

- Henry's Law constant $(K)$ for $\mathrm{O}_{2}$ and $\mathrm{CH}_{4}$ are 1.28 and $1.34 \mathrm{mmol} \mathrm{L}^{-1} \mathrm{~atm}^{-1}$, respectively.

- Dissolved $\mathrm{O}_{2}$ was calculated as: $K \times\left[\right.$ Headspace $\left.\mathrm{O}_{2}\right]$.

- Diffusivities of dissolved $\mathrm{O}_{2}$ and $\mathrm{CH}_{4}$ in water at $20^{\circ} \mathrm{C}$ are 2.06 and $1.75 \times 10^{-5} \mathrm{~cm}^{2} \mathrm{sec}^{-1}$, respectively (Broecker and Peng, 1974). Therefore, there's no diffusion limit of $\mathrm{O}_{2}$ for $\mathrm{CH}_{4}$ oxidation. 